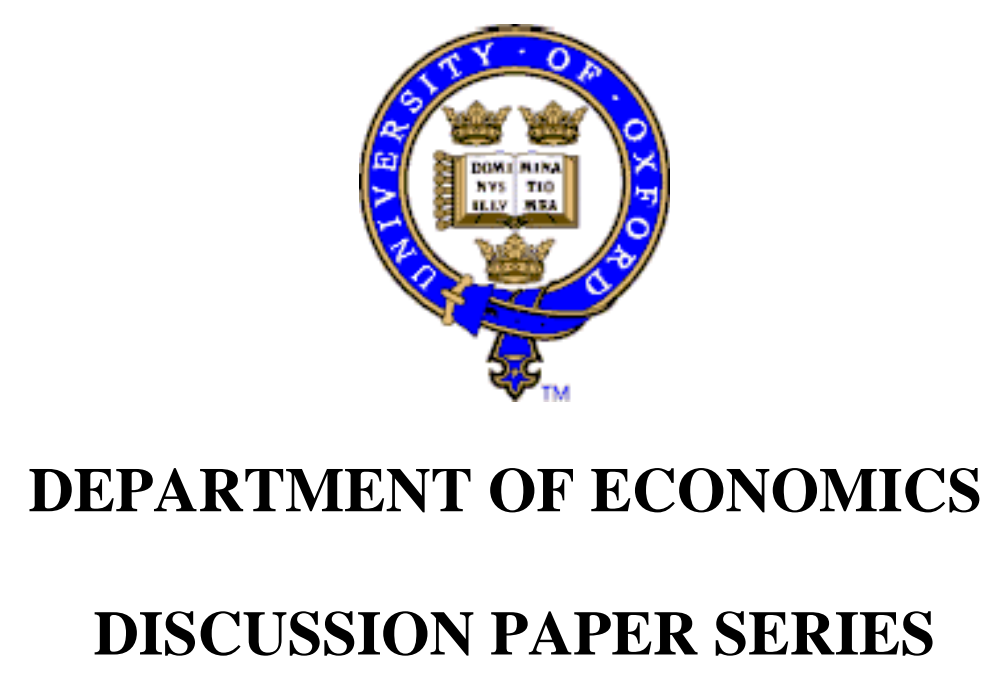

THE ROLE OF SOCIAL CAPITAL IN THE LABOUR MARKET IN CHINA

John Knight and Linda Y. Yueh

Number 121

October 2002 


\title{
The Role of Social Capital in the Labour Market in China
}

John Knight and Linda Yueh

July 2002

Department of Economics

University of Oxford

Manor Road Building

Oxford OX1 3UQ

UK

john.knight@economics.ox.ac.uk

\author{
St. Edmund Hall \\ Queens Lane \\ Oxford OX1 4AR \\ UK \\ linda.yueh@economics.ox.ac.uk
}

Correspondence. John Knight, Department of Economics, University of Oxford, Manor Road Building, Oxford OX1 3UQ, UK. Telephone: +44 1865 271069, Facsimile: +44 1865 271094. E-mail: john.knight@economics.ox.ac.uk.

JEL Classification Numbers. J30, J40.

Keywords. Labour markets, wages, social capital, social networks, China. 
Acknowledgements. The support of the Nuffield Foundation and the U.K. Department for International Development is gratefully acknowledged. 
Social capital is thought to play an economic role in the labour market. It may be particularly pertinent in one that is in transition from an administered to a market-oriented system. One factor that may determine success in the underdeveloped Chinese labour market is thus guanxi, the Chinese variant of social capital. With individual-level measures of social capital, we test for the role of guanxi using a data set designed for this purpose, covering 7,500 urban workers and conducted in early 2000. The basic hypothesis is supported. Both measures of social capital - size of social network and Communist Party membership - have significant and substantial effects in the income functions. Indeed, social capital may be just as important as human capital: remarkably, one additional reported contact contributes more than one additional year of education. Social capital can have influence either in an administered system or in one subject to market forces. We find that it does so in both parts of the labour market, but some of the evidence suggests that it is more important in the latter.
\end{abstract}




\section{Introduction}

The role of social capital in the economy has attracted widespread attention (for instance, Dasgupta and Serageldin 2000, and the World Bank Social Capital Initiative, working paper series). The work spans many areas, including economic growth and development (for instance, Putnam, Leonardi and Nanetti 1993, Knack and Keefer 1997), inter-firm linkages (for instance, Durlauf 1993, Fafchamps and Minten 1999), and the labour market (for instance, Granovetter 1995[1974]), Montgomery 1991).

A distinction can be drawn between the operation of social capital through social networks and through social norms. The term social capital - with its connotation of current sacrifice for future gain - is not necessarily appropriate in either case. According to Arrow (2000, pp. 3-5) “... the essence of social networks is that they are built up for reasons other than their economic value to the participants... that much of the reward for social interactions is intrinsic...." Similarly, the behaviour that generates such social norms as trust, reciprocity and co-operation need not be interpreted as the outcome of investment decisions. Nevertheless, the term social capital is often used, implying that social networks or social norms are economically valuable assets. We shall follow the practice.

Our interest is in the role of social capital in the Chinese labour market. China provides an excellent case study. First, an important aspect of Chinese society whether in traditional China (-1949), in the period of central planning (1949-1978), or in the period of economic reform (1978-) - is the Chinese variant of social capital known as guanxi. The social relationships that constitute guanxi are pervasive in both economic and

\footnotetext{
${ }^{1}$ However, he went on to qualify his argument (pp. 3-5): “... this is not to deny that social networks and other social links may also form for economic reasons. One line of reasoning is that the social networks guard against market failure...."
} 
non-economic life. Is guanxi important for success in the labour market? Second, the Chinese urban labour market is in a process of transition from an administered system, in which labour was allocated and wages were set institutionally, to one in which market forces play a role. In principle, guanxi can be used in either system. Is guanxi more or less important in the more competitive parts of the labour market?

The economic literature is divided between those who model social capital at the community level (for instance, Knack and Keefer 1997, Narayan and Pritchard 1999, Dasgupta 2000) and those who do so at the individual or household level. The latter approach is adopted here: we analyse the effects of social capital acquisition by individuals, whether motivated by social or economic considerations. The main contributions are twofold: our measures of social capital, and the comparative analysis of social capital in different labour market environments.

Section 2 draws on the relevant literature, both in general and on China, in order to develop hypotheses about the effects of social capital in the labour market. Section 3 explains our data set and provides the framework for testing. In Section 4 we present and interpret the empirical results. Section 5 concludes.

\section{Context and Hypotheses}

The notion that social institutions can address labour market failure has been investigated in the contexts of imperfect information and transaction costs. Various beneficial effects in the labour market have been attributed to social capital. Among them is better information (Granovetter 1995[1974], Waldinger 1996), decreased transaction costs 
(Abraham and Medoff 1983, Eccles and Crane 1988), increased efficiency (Burt 1992), or improved trust and other normative values (Akerlof 1982). Montgomery (1991) develops an adverse selection model in which a referral system using the contacts of current employees results in higher profits for the firm as well as in higher wages for the employees who have the requisite social contacts to make referrals. Social networks may thus assist job search and promotions and give rise to earnings premiums. Moreover, there is empirical evidence to support the arguments that social capital is valuable. Studies in the United States show the importance of referrals in recruitment (Granovetter 1995[1974], Waldinger 1996), and of associational affiliation (Bartlett and Miller 1985) or contacts (Mortensen and Vishwanath 1994) in raising wages.

Social capital and in particular guanxi - the relationships that an individual maintains in social networks - have been emphasised in the analysis of Chinese economic transactions (for instance, Bian 1994a, Wank 1995) as well as social life (for instance, Kipnis 1997, Yang 1994, Yan 1996). Oi (1999, p. 132) regards guanxi as the "operational code" for how best to get things done in China. The traditional strength of guanxi may stem from the lack of a comprehensive legal structure (McMillan 1995), and its more recent economic importance may be due to the inconsistent enforcement of laws (Yang 1994; Lee 1998), risk reduction in an uncertain socio-politico-economic environment (Walder 1986, Oi 1989, 1999), risk spreading in an economy characterised by shortages (Yan 1994, Kipnis 1997, Chang 1999), and information sharing in imperfect markets (Knight and Song 1999). Meals and gifts are common and effective methods of cultivating guanxi (Yan 1996, Kipnis 1997, Oi 1999). The associated gift economy is prevalent in both urban and rural China (Yang 1994). 
Turning specifically to the Chinese labour market: Bian (1994a) argues that guanxi was a determinant of employment success in the system of allocated jobs. In a case study over half of the state sector workers who were allocated their first job had used guanxi to help obtain the assignment; according to Bian (1994b), half of another sample of state sector workers who had changed jobs had used a contact to do so; Oi (1989) finds that contacts are important in hiring; Lee (1998) concludes that managers use referrals from current employees to generate goodwill and to reduce the chance of hiring undesirable workers. Knight and Song (1999) argue that the use of contacts improves the information of both recruiting firms and searching workers in an imperfect labour market. Guanxi can also raise earnings. Promotions and pay rises can depend on inside information and connections (Bian 1994a, Lee 1998).

The Chinese Communist Party has complete control of the organs of state in China, and the Party also reaches down to the lower levels of social organisation. There is a Party secretary in each village and a Party organisation in each work unit. Membership of the Party is not simply a matter of personal choice: recruits are vetted and selected. Membership involves acceptance of Party discipline but it may also provide information, contacts and influence. The positive relationship between Party membership and income is well known, although the direction of causation needs to be established (Knight and Song 1991, 1993). Party membership is thus a promising indicator of associational social capital in China.

Our basic hypothesis is that guanxi generates returns in the urban labour market. We shall use three measures of social capital - the size of a worker's social network, the worker's associational membership of the Communist Party, and the 
Communist Party membership of the worker's parents - as our measures of social capital.

Given support for the basic hypothesis, we go on to analyse the returns to guanxi in different parts of the labour market. In principle, guanxi can be important in either an administered system involving labour allocation and institutional wage determination or in a market-oriented system. In the former, guanxi may provide access to economic rents, and in the latter, guanxi may provide information and reduce transaction costs.

Three stratifications of the labour market will be analysed. Since 1995, the Chinese government has pursued a policy of reforming the state-owned enterprise sector. This has involved the retrenchment of over 25 million employees (Appleton et al., 2002). We contrast workers who have been retrenched - and who are thus more likely to have faced market forces as they searched for jobs - and those who have never been retrenched. We contrast age cohorts: the younger age cohorts are more likely to have encountered a labour market whereas the older cohorts generally continue to work in allocated jobs. Finally, we investigate whether returns to social capital differ by ownership sector, as state enterprises and urban collectives are associated with the administered labour system whereas private firms and the self-employed are more subject to labour market forces.

\section{Data}

The data set we use to test our hypotheses is an urban household survey designed by the Institute of Economics, Chinese Academy of Social Sciences in collaboration with foreign scholars and conducted by the NBS in February/March 2000; it 
pertains mainly to 1999 . The total sample size is 4,000 urban households. ${ }^{2}$ The survey covers six provinces and 13 cities. The provinces are Beijing (chosen to represent the four cities that are independently administered municipal districts), Liaoning (to represent the northeast), Henan (to represent the interior), Gansu (to represent the northwest), Jiangsu (to represent the coast), and Sichuan (to represent the southwest). The capital of each province is chosen as a city within the sampling frame - a total of three cities are chosen in Sichuan and Henan and two in each of the others, in addition to Beijing.

A module of the survey was designed to measure social capital at the individual level. The measures of social capital include the size of social networks, Communist Party membership and parents' Communist Party membership. The measurement of an individual's social network typically encompasses both the network's size and density (Burt 1992; Wasserman and Faust 1994). Size is the number of contacts in a social network and density is its inter-relatedness. For instance, an individual could have a large number of social contacts, but the contacts all know each other, so the network is denser and smaller than another individual's network in which few of the contacts know each other. There are more potential indirect contacts in the latter network. Our measure of social network is the reported number of contacts of an individual in any context, social or economic. The survey question asked: "In the past year, how many relatives, friends, colleagues or acquaintances did you exchange gifts with or often maintain contact?" For the

\footnotetext{
${ }^{2}$ 2,500 of these were NBS sample households and the remainder are from a representative sampling frame begun in 1999 that includes urban-residing households without urban hukou. In addition, independent samples are drawn of 500 households surveyed in which a member had experienced being laid-off and of 800 migrant households.
} 
working-aged population ${ }^{3}$ in the urban sample, the mean size of social network was 6.4 persons (Table 1). For those working-aged persons who have experienced some form of unemployment from the end of 1994 to the end of 1999, we find slightly smaller social networks (mean 5.3). For those who had not experienced unemployment in those five years, the mean size of their social network was larger than either (6.6). Among the age cohorts, those aged 31-41 have the largest networks (6.8). Workers who are in the state sector have the largest number of contacts in their social networks (6.6) and those who work in urban collectives the smallest (5.2).

The positive correlation between Communist Party membership and income is well known, although the direction of causation is difficult to establish (Knight and Song 1991, 1993). This measure of social capital accords with the notion of associational membership as proposed by Putnam, Leonardi and Nanetti (1993). Associational membership is often used in aggregative form to proxy the level of social capital in the community, rather than as an individual investment decision. Given the importance of the Communist Party in China's society and its power structure, the access to influence which it provides makes membership the most promising indicator of associational social capital. We also consider the role of parents' Communist Party membership as a form of guanxi from which children can benefit at a formative stage of their careers.

Some $17 \%$ of the urban sample are Communist Party members. Almost $25 \%$ of those who have never experienced unemployment are members, as compared with $10 \%$ of those who have done so. Among age cohorts, membership increases with age: the oldest age cohort has nearly $29 \%$. Finally, $27 \%$ of the state sector are members, whereas

\footnotetext{
${ }^{3}$ Working-aged individuals are defined as those aged 19-55 in consideration of the different retirement
} 
the figure is less than $10 \%$ for urban collectives and private firms and only $3 \%$ for the selfemployed. About $22 \%$ of the urban sample have one parent who is/was a Communist Party member and another $7 \%$ have both parents who are/were members. Many more have fathers who are/were Party members than have mothers. Again, individuals who work in the state sector are most likely to have one parent in the Party.

We estimate the determinants of both social network and Party membership to gain a better understanding of these variables (Table 2). Equation (1) is an OLS regression of the determinants of social network, while equation (2) is a logit estimation of the probability of becoming a Communist Party member for the working-age (19-55) population. There are few determinants of the size of social network. Aside from differences by city, the significant variables are gender, years of education and work experience. Being female reduces the number of contacts in a social network (significant at the 5\% level). Years of education and of work experience both increase the size of social network (significant at the $1 \%$ and $10 \%$ level, respectively). The coefficients on age are not significantly different from zero. An attitudinal question asking whether social connections have changed in importance is the last significant variable. The interpretation is that if the respondent thinks that social connections have increased in importance, he will have a larger social network. Notably, being a Communist Party member does not increase the number of contacts in a social network. When father and mother's Communist Party membership are separately estimated (unreported equation), we find that neither variable is significant.

In equation (2), we find that cities are significant determinants of Communist Party membership. The variables that increase the likelihood of becoming a Communist 
Party member are education, work experience, working in the state-owned sector, being a non-manual worker and being head of household. One or both parents who are or were Communist Party members also significantly increase the probability of own Party membership. Female gender significantly reduces the chance of becoming a Communist Party member. Again, it is notable that social networks are not a factor in the likelihood of Party membership. Finally, an attitudinal question that asks whether the respondent hopes that her children will become Party members is also a significant determinant.

It appears that a person's social network is a phenomenon whose determinants are not well measured by an economic survey, whereas Communist Party membership is more closely determined by his or her economic characteristics. This suggests that social networks are more likely than Communist Party membership to be built up for reasons other than economic returns, such as friendship or social relations. Finally, neither social network nor Communist Party membership is a determinant of the other, indicating that they are distinct phenomena.

\section{Empirical investigation}

Our analysis begins with estimating the determinants of income for the entire urban sample. Later we partition the sample into different segments that accord with our hypotheses concerning the role of social capital in the administered versus the marketoriented parts of the labour market. Each of the tables presents an income function that does not include the social capital variables to indicate the returns to personal characteristics, human capital, etc. We then introduce the social capital variables to see what difference, if any, they make and whether their effects are significant in determining 
income. In each formulation, we estimated the income functions by ordinary least squares (OLS), selection-corrected maximum likelihood (MLE), and two-stage least squares (2SLS) with an instrument for any endogenous variable. The exclusion restrictions for the MLE and the instruments for the 2SLS are reported in the notes accompanying each table. For the purposes of interpretation, we use the MLE figures except where the social capital variables are found to be endogenous. The MLE estimates are used because OLS estimates are biased on account of sample selection into employment. If the social capital variables are endogenous, we use an instrument and present the resultant 2SLS estimates. The test for endogeneity is the standard Durban-Wu-Hausman test evaluated at the $5 \%$ level of significance. We report all estimates in the tables for the whole sample. For brevity, we report only the pertinent estimates for the remaining tables.

In Table 3, we estimate the determinants of income for the entire urban sample of employed individuals. Compare the most appropriate equations without (equation (2)) and with (equation (5)) the social network variable. We choose these because the inverse Mills ratio is significant in equation (2) and social networks are found to be endogenous. In equation (2), regarding productive characteristics, there is a $4.9 \%$ return to each year of education and a $2.1 \%$ return to each year of employment experience at the mean value of employment experience. There is a large gender earnings gap: women are paid $18 \%$ less than men. We also control for the ownership sector of the employer and occupation, but focus our discussion on the human capital and social capital variables. In equation (5), social network is found to generate a positive income premium of $10 \%$ and is significant at the $10 \%$ level. The returns to education fall from $4.9 \%$ to $2.5 \%$ per annum. Returns to employment experience likewise fall to $1.6 \%$ per annum. 
Interestingly, the gender gap falls to $12 \%$. Our findings suggest that there is correlation between social network and the human capital and gender variables. When it is omitted, the returns to gender, education and experience are overstated. For instance, part of the gender gap can be attributed to differences in social network.

In equation (7), there is a $13 \%$ income premium associated with Communist Party membership, which is significant at the $1 \%$ level. The human capital and the gender coefficients remain largely unaffected by its inclusion. When both social network and Communist Party membership are introduced, in equation (10), we find an approximate $10 \%$ income premium associated respectively with each variable.

We conclude from Table 3 that our basic hypothesis is supported. There are indeed significant and substantial returns to both of our social capital variables, social network and Communist Party membership. Moreover, the social network and the other personal variables are correlated. Thus, part of the gender gap may arise from gender differences in social networks. Insofar as the correlation between education and social network is non-causal, one more member in a social network is worth more than one more year of education; insofar as education expands a social network, the latter coefficient indicates a mechanism by which education raises pay.

Table 4 differs from Table 3 only in that we introduce parents' membership of the Communist Party in addition to our other two social capital variables. We see in equation (2) that having both parents who are (or were) Party members has a substantial and significant effect on earnings, and one which is larger than having only one parent a 
member. ${ }^{4}$ When social network is also introduced (equation (5)) parental membership, although positive, ceases to be significant. Similarly, when all the social capital variables are included and the endogenous variable, social network, is instrumented, the coefficients on social network and Party membership remain substantial and significant but the parental Party membership variables, although positive, become insignificant (equation (10)). The returns to social network and to human capital from Table 3 are not affected by the guanxi of an individual's parents. In the overall sample, then, the social capital provided by parents is not beneficial.

Table 5 distinguishes individuals who have never been unemployed and those who have been laid-off at some point between 1994 and 1999. The former are likely to be in the more institutional part of the labour market and the latter likely to have encountered market forces. There is indeed a contrast: although the coefficients on the social capital variables are of similar size for these two groups, they are generally significant for workers who had never been retrenched and not significant for those who had been (equations (5) and (10)). We can therefore be more confident that social capital is valuable for unretrenched workers. For the unretrenched, the human capital variables are rewarded. They are reduced by the inclusion of the social capital variables but remain significant (equations (6) and (10)). The results for this (predominant) group are very similar to those for the sample as a whole (Table 3). Both human and social capital are valuable in that part of the labour market more closely associated with the planned rather than the market economy.

\footnotetext{
${ }^{4}$ When the Party memberships of the father and of the mother are distinguished and both are introduced (without the other social capital variables) each has a significantly positive effect on income (equations are not reported).
} 
Even in the absence of social capital, the returns to education and

employment experience are lower and the gender gap larger for the retrenched than for the unretrenched (equations (1) and (6)). With the inclusion of social capital, the gender gap remains large and significant (women are paid 20\% less than men, ceteris paribus), but the returns to human capital are insignificant. It appears that neither human nor social capital is valuable for the retrenched workers. Many of them were flung onto a tough, unwelcoming labour market in which jobs which would match their skills, and jobs with which their networks could help them, were very scarce.

Table 6 divides the sample into three age cohorts. The oldest cohort, aged $42-55$, is the group most likely to have been allocated jobs during the period of central planning, and many were in the same jobs in 1999. The youngest cohort, aged 19-30, probably entered the labour force during the 1990s, when the allocation system had broken down or weakened and entrants generally had to search for their own jobs in the emerging labour market.

We find that social network does not benefit the oldest age cohort, whereas Party membership, and even parental Party membership, does. Indeed, the parental variable is only significant for the oldest cohort. It appears that parental Party membership was important in securing a favourable job allocation under central planning, and that own Party membership assisted the subsequent careers of the oldest cohort. Social network is significant for the youngest and middle cohorts, but the coefficient is lower for the former. For labour market entrants, parental social network (not measured in the survey) may be more important than own social network. Finally, the coefficient on own Party membership is positive, significant, and more or less the same for all three cohorts. 
Four ownership sectors are distinguished in Table 7. The most important category, accounting for $76 \%$ of employees, is the state sector, followed by urban collectives (14\%), private firms (7\%) and the self-employed (3\%). The recent reforms have given greater managerial autonomy to state-owned enterprises (SOEs), including a degree of freedom to manage workers. Nevertheless, the ownership sector is the one least affected by labour market forces. The difference between SOEs and urban collectives is not large, except that collectives are more likely to face 'hard' budgets. Labour market forces are most likely to be experienced in the private sector. The self-employment sector is also subject to market forces, but the nature and role of social capital is probably different for the self-employed.

Indeed, we see in Table 7 that social capital does not assist the selfemployed. To explain its role in this case, we need different measures of social capital, such as networks of business associates. The social network variable is positive and significant in all three of the sectors offering paid employment, as is the Party membership variable. Both variables are biggest in the private sector (compare equations (4), (6) and (10)). It appears that social capital is important in both the administered and the market-oriented parts of the labour market, but it is more important in the more market-oriented part.

It is worth pointing out an unexpected result. Whereas the returns to employment experience are highest in the private sector, the returns to education are lowest there, and the inclusion of the social capital variables reduces them to zero (equations (9) and (10)). This does not fit the argument that, given the egalitarianism of the state sector, the rewards for human capital, including education, should be higher in the more marketoriented, private sector. But, it does suggest that those better able to enter the private 
sector have experience that is sought by new private firms which in turn reward these workers for the contacts and connections that are valuable in an uncertain market.

\section{Conclusion}

Our main objective in this paper was to discover whether social capital plays a role in the urban labour market in China. We found persuasive evidence in support of our basic hypothesis. Both our measure of social network and our measure of associational social capital, Communist Party membership, raise the incomes of employed persons. Social capital appears to be important by comparison with human capital. Remarkably, one additional reported contact contributes more to earned income than an additional year of schooling! It is possible that our measures are correlated with unobserved personal characteristics, such as sociability. However, it is likely that such personal characteristics enhance income through their effects in expanding social networks and encouraging associational memberships. Thus networks and memberships play an economic role - which accords with the findings of others who have investigated social networks and reached a similar conclusion (for instance, see Granovetter 1995 [1974] and Rebick 2000).

Our secondary objective was to understand the mechanisms by which social capital has its effects. We saw a potential role for it both in an administered labour system, where jobs are allocated and wages are institutionally determined, and in a market-oriented system - especially an underdeveloped one - where labour market information is poor and transaction costs are high. Our results were rather mixed. Our measure of network is more important for the middle than for the youngest or the oldest age cohorts, possibly because the forms of social capital relevant to the other two groups are different: parental Communist 
Party membership was important under central planning and parental social networks may be important for labour market entrants. Social capital is more valuable for the majority of workers who have never been retrenched than for the minority who have recently been. The latter appear to be in a tough labour market in which jobs which match their skills, or for which their social networks can help, are very scarce. Social networks appear to be more beneficial in the private sector than in the state or urban collective sectors. Since this is the rapidly expanding sector, the expectation must be that guanxi will continue to play an important role in the Chinese labour market.

This paper makes a contribution to the literature on social capital, both for China and more generally. For China, it is the first to create and use a successful quantitative measure of social network. Placed within the social capital literature generally, it is unusual in providing an individual-level measure, in contrast to community-level or binary measures of whether an individual has or does not have social capital. Our relatively simple measure was successful. Nevertheless, future research should explore the multiple facets and dimensions of social capital. The composition of a social network may influence the range of possible returns. For instance, Montgomery (1991) distinguishes by skill level and Moore (1990) by the nature (kin, colleague, friend, etc.) of the relationship, and Yueh (2001) models the amount of capital within a given network. 


\section{References}

Abraham, K. and J. Medoff. 1983. Length of Service and the Operation of Internal Labor Markets. Sloan School of Management Working Paper No. 1394-83. Massachusetts Institute of Technology, Cambridge, Massachusetts.

Akerlof, G.A. 1982. Labor Contracts as Partial Gift Exchange. The Quarterly Journal of Economics 97(4), 543-569.

Arrow, K.J. 2000. Observations on Social Capital. Social Capital: A Multifaceted Perspective. P. Dasgupta and I. Serageldin, eds. Washington DC: The World Bank.

Bartlett, R.L. and T.I. Miller. 1985. Executive Compensation: Female Executives and Networking. The American Economic Review 72(2), 266-270.

Bian, Y. 1994a. Guanxi and the Allocation of Urban Jobs in China. The China Quarterly 140, 971-999.

Bian, Y. 1994b. Work and Inequality in Urban China. Albany: State University of New York.

Burt, R.S. 1992. Structural Holes: The Social Structure of Competition. Cambridge, Massachusetts: Harvard University Press.

Chang, X. 1999. "Fat Pigs" and Women's Gifts: Agnatic and Non-Agnatic Social Support in Kaixiangong Village. Women of China: Economic and Social Transformation. J. West, M. Zhao, X. Chang and Y. Cheng, eds. Basingstoke: Macmillan.

Chen, L. 1999. Expanding Women's Co-operatives in China through Institutional Linkages. Development and Change 30(1999), 715-738.

Dasgupta, P. 2000. Economic Progress and the Idea of Social Capital. Social Capital: A Multifaceted Perspective. P. Dasgupta and I. Serageldin, eds. Washington DC: The World Bank.

Durlauf, S.N. 1993. Nonergodic Economic Growth. The Review of Economics and Statistics 60(2), 349-366.

Eccles, R.G. and D.B. Crane. 1988. Doing Deals: Investment Banks at Work. Boston: Harvard Business School Press. 
Fafchamps, M. and B. Minten. Forthcoming, Oxford Economic Papers. Returns to Social Network Capital Among Traders. Mimeo, Department of Economics, University of Oxford. Oxford, UK.

Granovetter, M. 1995 [1974]. Getting a Job: A Study of Contacts and Careers. Chicago: University of Chicago Press.

Granovetter, M. 1985. Economic Action and Social Structure: The Problem of Embeddedness. The American Journal of Sociology 91(3), 481-510.

Greene, W.H. 1997 [1993]. Econometric Analysis. New Jersey: Prentice-Hall, Inc.

Greif, A. 1993. Contract Enforceability and Economic Institutions in Early Trade: The Maghribi Traders' Coalition. The American Economic Review 83(3), 525-548.

Kipnis, A.B. 1997. Producing Guanxi. Durham, North Carolina: Duke University Press.

Knack, S. and P. Keefer. 1997. Does Social Capital Have an Economic Payoff? A Cross-Country Investigation. The Quarterly Journal of Economics 112(4), 1251-1288.

Knight, J. and L. Song. 1991. The Determinants of Urban Income Inequality in China. Oxford Bulletin of Economics and Statistics 53(2), 123-154.

Knight, J. and L. Song. 1993. Why Urban Wages Differ? In K. Griffin and R. Zhao, eds., The Distribution of Income in China. London: Macmillan.

Knight, J. and L. Song. 1999. The Rural-Urban Divide: Economic Disparities and Interactions in China. Oxford: Oxford University Press.

Landa, J.T. 1994. Trust, Ethnicity and Identity: Beyond the New Institutional Economics of Ethnic Trading Networks, Contract Law and Gift Exchange. Ann Arbor: University of Michigan Press.

Lee, C.K. 1998. Gender and the South China Miracle: Two Worlds of Factory Women. Berkeley: University of California Press. 
McMillan, J. 1995. Markets in Transition. Graduate School of International Relations and Pacific Studies, Research Report No. 95-06, 1-34.

Montgomery, J.D. 1991. Social Networks and Labor-Market Outcomes: Toward an Economic Analysis. The American Economic Review 81(5), 1408-1418.

Moore, G. 1990. Structural Determinants of Men's and Women's Personal Networks. The American Sociological Review 55(5), 726-735.

Mortensen, D.T. and T. Vishwanath. 1994. Personal Contacts and Earnings: It's Who You Know! Labour Economics 1(2), 187-201.

Narayan, D. and L. Pritchett. 1997. Cents and Sociability: Household Income and Social Capital in Rural Tanzania. Mimeo. Washington DC: The World Bank.

Oi, J.C. 1989. State and Peasant in Contemporary China: The Political Economy of Village Government. Berkeley: University of California Press.

Oi, J.C. 1999. Rural China Takes Off: Institutional Foundations of Economic Reform. Berkeley: University of California Press.

Putnam, R.D., R. Leonardi and R.Y. Nanetti. 1993. Making Democracy Work. Princeton: Princeton University Press.

Rebick, M.E. 2000. The Importance of Networks in the Market for University Graduates in Japan: A Longitudinal Analysis of Hiring Patters. Oxford Economic Papers 52(3), 471-496.

Walder, A.G. 1986. Communist Neo-Traditionalism: Work and Authority in Chinese Industry. Berkeley: University of California Press.

Waldinger, R. 1996. Still the Promised City: African-Americans and New Immigration in Postindustrial New York. Cambridge, Massachusetts: Harvard University Press. 
Wank, D.L. 1995. Bureaucratic Patronage and Private Business: Changing Networks of Power in Urban China. The Waning of the Communist State: Economic Origins of Political Decline in China and Hungary. A.G. Walder, ed. Berkeley: University of California Press.

Yan, Y. 1996. The Flow of Gifts: Reciprocity and Social Networks in a Chinese Village. Palo Alto, California: Stanford University Press.

Yang, M.M. 1994. Gifts, Favors and Banquets: The Art of Social Relationships in China. Ithaca, New York: Cornell University Press.

Young, S. 1995. Private Business and Economic Reform in China. Armonk, New York: M.E. Sharpe.

Yueh, L.Y. 2001. Gender, Discrimination and Inequality in China: Some Economic Aspects. D.Phil. thesis, Department of Economics, University of Oxford, UK. 
Table 1

Size of Social Networks and Communist Party Membership for the Working-Aged Urban Sample by Segments (standard deviation)

\begin{tabular}{|c|c|c|c|c|c|c|}
\hline \multirow[t]{2}{*}{$\begin{array}{c}\text { Segment } \\
\text { (number of } \\
\text { observations) } \\
\end{array}$} & \multirow[t]{2}{*}{$\begin{array}{l}\text { Social Networks } \\
\text { (number) }\end{array}$} & \multirow[t]{2}{*}{$\begin{array}{c}\text { Communist } \\
\text { Party Member } \\
(\%) \\
\end{array}$} & \multicolumn{2}{|c|}{$\begin{array}{c}\text { Parents' Communist } \\
\text { Party Membership } \\
(\%)\end{array}$} & \multicolumn{2}{|c|}{$\begin{array}{l}\text { Father and Mother } \\
\text { Communist Party } \\
\text { Membership (\%) }\end{array}$} \\
\hline & & & One & Both & Dad & Mom \\
\hline $\begin{array}{c}\text { Whole Sample } \\
(7501) \\
\end{array}$ & $\begin{array}{c}6.40 \\
(6.6469) \\
\end{array}$ & $\begin{array}{c}23.28 \\
(0.4227) \\
\end{array}$ & $\begin{array}{c}29.62 \\
(0.4566) \\
\end{array}$ & $\begin{array}{c}8.93 \\
(0.2852) \\
\end{array}$ & $\begin{array}{c}34.63 \\
(0.4758) \\
\end{array}$ & $\begin{array}{c}11.06 \\
(0.3137) \\
\end{array}$ \\
\hline \multicolumn{7}{|l|}{$\begin{array}{l}\text { By Laid-off } \\
\text { Experience }\end{array}$} \\
\hline $\begin{array}{l}\text { Laid-off } \\
\text { Sample } \\
(1026)\end{array}$ & $\begin{array}{c}5.34 \\
(4.7998)\end{array}$ & $\begin{array}{c}11.41 \\
(0.3181)\end{array}$ & $\begin{array}{c}25.83 \\
(0.4379)\end{array}$ & $\begin{array}{c}5.85 \\
(0.2348)\end{array}$ & $\begin{array}{c}27.68 \\
(0.4477)\end{array}$ & $\begin{array}{c}7.29 \\
(0.2600)\end{array}$ \\
\hline $\begin{array}{c}\text { Never Laid-off } \\
\text { Sample (6475) } \\
\end{array}$ & $\begin{array}{c}6.58 \\
(6.8920) \\
\end{array}$ & $\begin{array}{c}25.16 \\
(0.4340) \\
\end{array}$ & $\begin{array}{c}30.22 \\
(0.4593) \\
\end{array}$ & $\begin{array}{c}9.42 \\
(0.2921) \\
\end{array}$ & $\begin{array}{c}35.83 \\
(0.4795) \\
\end{array}$ & $\begin{array}{c}11.71 \\
(0.3216) \\
\end{array}$ \\
\hline \multicolumn{7}{|l|}{$\begin{array}{l}\text { ByAge } \\
\text { Cohorts }\end{array}$} \\
\hline $\begin{array}{c}\text { Aged 19-30 } \\
(1530)\end{array}$ & $\begin{array}{c}5.73 \\
(5.6137) \\
\end{array}$ & $\begin{array}{c}7.81 \\
(0.2685) \\
\end{array}$ & $\begin{array}{c}38.43 \\
(0.4866) \\
\end{array}$ & $\begin{array}{c}14.77 \\
(0.3549) \\
\end{array}$ & $\begin{array}{c}45.00 \\
(0.4977) \\
\end{array}$ & $\begin{array}{r}19.13 \\
(0.3935) \\
\end{array}$ \\
\hline $\begin{array}{c}\text { Aged 31-41 } \\
(2452)\end{array}$ & $\begin{array}{c}6.77 \\
(6.8195) \\
\end{array}$ & $\begin{array}{c}20.81 \\
(0.4060) \\
\end{array}$ & $\begin{array}{c}35.28 \\
(0.4779) \\
\end{array}$ & $\begin{array}{c}9.62 \\
(0.2950) \\
\end{array}$ & $\begin{array}{c}42.10 \\
(0.4938) \\
\end{array}$ & $\begin{array}{c}12.05 \\
(0.3256) \\
\end{array}$ \\
\hline $\begin{array}{c}\text { Aged 42-55 } \\
(3337)\end{array}$ & $\begin{array}{c}6.35 \\
(6.8123) \\
\end{array}$ & $\begin{array}{c}32.63 \\
(0.4689) \\
\end{array}$ & $\begin{array}{c}21.25 \\
(0.4091) \\
\end{array}$ & $\begin{array}{c}5.27 \\
(0.2236) \\
\end{array}$ & $\begin{array}{c}25.31 \\
(0.4349) \\
\end{array}$ & $\begin{array}{c}7.22 \\
(0.2589) \\
\end{array}$ \\
\hline \multicolumn{7}{|l|}{$\begin{array}{c}\text { By Sector of } \\
\text { Employer }\end{array}$} \\
\hline $\begin{array}{c}\text { State Sector } \\
(5127)\end{array}$ & $\begin{array}{c}6.62 \\
(6.6138) \\
\end{array}$ & $\begin{array}{c}29.36 \\
(0.4555) \\
\end{array}$ & $\begin{array}{c}30.80 \\
(0.4617) \\
\end{array}$ & $\begin{array}{c}9.38 \\
(0.2916) \\
\end{array}$ & $\begin{array}{c}37.15 \\
(0.4833) \\
\end{array}$ & $\begin{array}{c}11.65 \\
(0.3208) \\
\end{array}$ \\
\hline $\begin{array}{c}\text { Urban } \\
\text { Collectives } \\
(925) \\
\end{array}$ & $\begin{array}{c}5.24 \\
(5.0885)\end{array}$ & $\begin{array}{c}11.90 \\
(0.3240)\end{array}$ & $\begin{array}{c}22.16 \\
(0.4156)\end{array}$ & $\begin{array}{c}4.54 \\
(0.2083)\end{array}$ & $\begin{array}{c}22.68 \\
(0.4190)\end{array}$ & $\begin{array}{c}5.83 \\
(0.2344)\end{array}$ \\
\hline $\begin{array}{c}\text { Self-Employed } \\
\text { (219) }\end{array}$ & $\begin{array}{c}6.51 \\
(11.7954) \\
\end{array}$ & $\begin{array}{c}3.20 \\
(0.1763) \\
\end{array}$ & $\begin{array}{c}26.03 \\
(0.4398)\end{array}$ & $\begin{array}{c}5.48 \\
(0.2281) \\
\end{array}$ & $\begin{array}{c}24.29 \\
(0.4298)\end{array}$ & $\begin{array}{c}8.10 \\
(0.2734) \\
\end{array}$ \\
\hline $\begin{array}{c}\text { Private Firms } \\
\text { (499) }\end{array}$ & $\begin{array}{c}6.53 \\
(6.7862)\end{array}$ & $\begin{array}{c}15.63 \\
(0.3635)\end{array}$ & $\begin{array}{c}32.36 \\
(0.4680)\end{array}$ & $\begin{array}{c}10.62 \\
(0.3084)\end{array}$ & $\begin{array}{c}36.42 \\
(0.4817) \\
\end{array}$ & $\begin{array}{c}14.99 \\
(0.3573) \\
\end{array}$ \\
\hline
\end{tabular}

Source: Urban Household Survey, 1999. 
Table 2

First Stage Instrumenting Regressions: The Determinants of Social Networks and Party Membership

\begin{tabular}{|c|c|c|c|}
\hline $\begin{array}{l}\text { Dependent Variable: } \\
\text { (1) Social network: size }\end{array}$ & \multicolumn{2}{|c|}{$\begin{array}{l}\text { Coefficient } \\
\text { (t-statistic) }\end{array}$} & \multirow[t]{2}{*}{$\begin{array}{l}\text { Mean Value or Percentag } \\
\text { (standard deviation) }\end{array}$} \\
\hline & $(1)$ & $(2)$ & \\
\hline Intercept & $\begin{array}{l}-2.6214 \\
(-0.624) \\
\end{array}$ & $\begin{array}{l}-11.7840 \\
(-11.060)^{* * *}\end{array}$ & \\
\hline \multicolumn{4}{|l|}{$\underline{\text { Personal Characteristics }}$} \\
\hline Gender & $\begin{array}{l}-0.5689 \\
(-2.142) * * \\
\end{array}$ & $\begin{array}{c}-0.5985 \\
(-8.733) * * * \\
\end{array}$ & $\begin{array}{c}0.5017 \\
(0.5000) \\
\end{array}$ \\
\hline Age & $\begin{array}{l}-0.0563 \\
(-0.275) \\
\end{array}$ & $\begin{array}{c}0.0945 \\
(2.093) * * * \\
\end{array}$ & $\begin{array}{l}37.1451 \\
(9.5394) \\
\end{array}$ \\
\hline Age squared & $\begin{array}{l}0.0003 \\
(0.119) \\
\end{array}$ & $\begin{array}{l}-0.0007 \\
(-1.384) \\
\end{array}$ & $\begin{array}{l}1470.7520 \\
(709.2652) \\
\end{array}$ \\
\hline Years of education & $\begin{array}{l}0.1559 \\
(2.707) * * * \\
\end{array}$ & $\begin{array}{c}0.1675 \\
(10.559)^{* * *} \\
\end{array}$ & $\begin{array}{l}10.2976 \\
(2.9891) \\
\end{array}$ \\
\hline Years of employment experience & $\begin{array}{l}0.0565 \\
(1.700)^{*} \\
\end{array}$ & $\begin{array}{l}0.0590 \\
(5.403) * * *\end{array}$ & $\begin{array}{l}19.4816 \\
(9.1166) \\
\end{array}$ \\
\hline Head of household & $\begin{array}{l}-0.4945 \\
(-1.161) \\
\end{array}$ & $\begin{array}{c}0.3571 \\
(5.224) * * * \\
\end{array}$ & $\begin{array}{c}0.3930 \\
(0.4885) \\
\end{array}$ \\
\hline \multicolumn{4}{|l|}{ Ownership Sector of Employer } \\
\hline State-owned sector & $\begin{array}{l}0.2531 \\
(0.472) \\
\end{array}$ & $\begin{array}{c}0.3845 \\
(2.972) * * * \\
\end{array}$ & $\begin{array}{c}0.5359 \\
(0.4987) \\
\end{array}$ \\
\hline Private sector & $\begin{array}{l}-0.2466 \\
(-0.410) \\
\end{array}$ & $\begin{array}{l}-0.1941 \\
(-1.050) \\
\end{array}$ & $\begin{array}{c}0.2476 \\
(0.4316) \\
\end{array}$ \\
\hline \multicolumn{4}{|l|}{ Occupation } \\
\hline Non-manual worker & $\begin{array}{l}-0.0578 \\
(-0.094) \\
\end{array}$ & $\begin{array}{c}1.2095 \\
(8.915) * * * \\
\end{array}$ & $\begin{array}{c}0.3591 \\
(0.4798) \\
\end{array}$ \\
\hline Production worker & $\begin{array}{l}-0.5468 \\
(-0.847) \\
\end{array}$ & $\begin{array}{l}-0.0361 \\
(-0.238) \\
\end{array}$ & $\begin{array}{r}0.1832 \\
(0.3869) \\
\end{array}$ \\
\hline Self-employed & $\begin{array}{l}-0.0034 \\
(-0.004) \\
\end{array}$ & $\begin{array}{l}0.1544 \\
(0.445) \\
\end{array}$ & $\begin{array}{c}0.0100 \\
(0.0996) \\
\end{array}$ \\
\hline Other occupations & $\begin{array}{l}-0.7679 \\
(-1.052) \\
\end{array}$ & $\begin{array}{l}0.1942 \\
(0.879) \\
\end{array}$ & $\begin{array}{c}0.0485 \\
(0.2148) \\
\end{array}$ \\
\hline \multicolumn{4}{|l|}{ Guanxi } \\
\hline Communist Party member & $\begin{array}{l}0.3724 \\
(1.230) \\
\end{array}$ & $\overline{---}$ & $\begin{array}{c}0.1736 \\
(0.3788) \\
\end{array}$ \\
\hline Social network & --- & $\begin{array}{l}0.0056 \\
(1.384) \\
\end{array}$ & $\begin{array}{c}6.4134 \\
(9.5384) \\
\end{array}$ \\
\hline \multicolumn{4}{|l|}{ Parents' Characteristics } \\
\hline $\begin{array}{l}\text { One parent is a member of the Communist } \\
\text { Party }\end{array}$ & $\begin{array}{l}0.1414 \\
(0.523) \\
\end{array}$ & $\begin{array}{l}0.3825 \\
(4.955)^{* * *}\end{array}$ & $\begin{array}{c}0.2228 \\
(0.4162) \\
\end{array}$ \\
\hline $\begin{array}{c}\text { Both parents are members of the } \\
\text { Communist Party }\end{array}$ & $\begin{array}{l}0.0281 \\
(0.051) \\
\end{array}$ & $\begin{array}{c}0.5223 \\
(4.229)^{* * *} \\
\end{array}$ & $\begin{array}{c}0.0664 \\
(0.2491) \\
\end{array}$ \\
\hline Father is/was not an unskilled worker & & $\begin{array}{c}0.3415 \\
(2.744)^{* * *}\end{array}$ & $\begin{array}{r}0.9374 \\
(0.2423) \\
\end{array}$ \\
\hline$\underline{\text { Cities }}$ & Yes & Yes & \\
\hline $\begin{array}{c}\mathrm{R}^{2} \\
\text { Pseudo } \mathrm{R}^{2} \\
\mathrm{~F}(29,2971) \\
\text { Wald } \mathrm{X}^{2}(29) \\
\text { Number of observations }\end{array}$ & $\begin{array}{l}0.0651 \\
--- \\
14.08 * * * \\
--- \\
2972\end{array}$ & $\begin{array}{l}--- \\
0.2460 \\
--- \\
1192.39 * * * \\
6568\end{array}$ & \\
\hline
\end{tabular}

Notes: (1) Omitted dummy variables are: male, non-Communist Party members, not head of

household, works in urban collectives, unskilled worker, whose parents are not Communist Party members, whose father is an unskilled worker, and Pinliang.

(2) $* * *$ denotes statistical significance at the $1 \%$ level, $* *$ at $5 \%$ level, and $*$ at $10 \%$ level.

(3) Heteroskedasticity-consistent robust adjusted for clustering at the household level are computed. 
Table 3

The Determinants of Income for Employed Individuals (aged 19-55) in the Urban Sample (with own guanxi variables)

\begin{tabular}{|c|c|c|c|c|c|c|c|c|c|c|}
\hline \multicolumn{11}{|l|}{ Dependent } \\
\hline \multirow{4}{*}{$\begin{array}{l}\text { Variable: } \\
\text { Log of } \\
\text { annual } \\
\text { income }\end{array}$} & \multirow{2}{*}{\multicolumn{10}{|c|}{$\begin{array}{l}\text { Coefficient } \\
\text { (t-statistic) }\end{array}$}} \\
\hline & & & & & & & & & & \\
\hline & (1) & (2) & (3) & (4) & (5) & (6) & (7) & (8) & (9) & (10) \\
\hline & OLS & MLE & $\begin{array}{c}\text { OLS } \\
\text { with SN }\end{array}$ & $\begin{array}{c}\text { MLE } \\
\text { with SN }\end{array}$ & $\begin{array}{c}2 \text { SLS } \\
\text { with SN }\end{array}$ & $\begin{array}{c}\text { OLS } \\
\text { with CP }\end{array}$ & $\begin{array}{c}\text { MLE } \\
\text { with CP }\end{array}$ & $\begin{array}{c}\text { OLS } \\
\text { with SN } \\
\text { and CP }\end{array}$ & $\begin{array}{c}\text { MLE } \\
\text { with SN } \\
\text { and CP }\end{array}$ & $\begin{array}{c}2 \mathrm{SLS} \\
\text { with SN } \\
\text { and } \mathrm{CP}\end{array}$ \\
\hline Intercept & $\begin{array}{c}7.1839 \\
(114.095)^{* *}\end{array}$ & $\begin{array}{c}7.3349 \\
(112.982)^{* * * *}\end{array}$ & $\begin{array}{c}7.1763 \\
(103.755)^{*}\end{array}$ & $\begin{array}{c}7.3041 \\
(102.755)^{* *}\end{array}$ & $\begin{array}{c}6.9102 \\
(30.088)^{* *}\end{array}$ & $\begin{array}{c}7.2295 \\
(114.856) * * *\end{array}$ & $\begin{array}{c}7.3796 \\
(113.547)^{*}\end{array}$ & $\begin{array}{c}7.3039 \\
(106.272)^{*}\end{array}$ & $\begin{array}{c}7.3508 \\
(103.063)^{* *}\end{array}$ & $\begin{array}{c}6.9458 \\
(30.130)^{* *}:\end{array}$ \\
\hline & $*$ & & $* *$ & $*$ & * & & $* *$ & $* *$ & $*$ & \\
\hline \multicolumn{11}{|l|}{$\underline{\text { Guanxi }}$} \\
\hline $\begin{array}{c}\text { Social } \\
\text { network }\end{array}$ & -- & --- & $\begin{array}{c}\mathbf{0 . 0 0 3 7} \\
(\mathbf{1 . 8 7 8})^{*}\end{array}$ & $\begin{array}{c}\mathbf{0 . 0 0 3 4} \\
(\mathbf{1 . 8 2 7})^{*}\end{array}$ & $\begin{array}{c}\text { 0.1021 } \\
(1.924)^{*}\end{array}$ & --- & --- & $\begin{array}{c}\mathbf{0 . 0 0 3 6} \\
(\mathbf{1 . 9 9 5})^{*} \\
*\end{array}$ & $\begin{array}{c}\mathbf{0 . 0 0 3 3} \\
(\mathbf{1 . 8 3 3})^{*}\end{array}$ & $\begin{array}{c}\text { 0.0981 } \\
(\mathbf{1 . 8 7 7})^{*}\end{array}$ \\
\hline $\begin{array}{c}\text { Communist } \\
\text { Party } \\
\text { member }\end{array}$ & -- & --- & --- & -- & -- & $\begin{array}{c}\mathbf{0 . 1 3 9 0} \\
(\mathbf{8 . 0 1 0})^{* * *}\end{array}$ & $\begin{array}{c}\mathbf{0 . 1 3 3 1} \\
(\mathbf{7 . 5 8 5})^{* *} \\
*\end{array}$ & $\begin{array}{c}0.1348 \\
(7.226) * * \\
*\end{array}$ & $\begin{array}{c}\mathbf{0 . 1 3 3 8} \\
(\mathbf{7 . 1 1 2})^{* *} \\
*\end{array}$ & $\begin{array}{c}\mathbf{0 . 0 9 8 0} \\
(2.059) * \\
*\end{array}$ \\
\hline \multicolumn{11}{|l|}{$\begin{array}{c}\text { Personal } \\
\text { Characteristics }\end{array}$} \\
\hline Gender & $\begin{array}{c}-0.2057 \\
(- \\
15.072)^{* * *}\end{array}$ & $\begin{array}{c}-0.1950 \\
(- \\
13.984)^{* * * *}\end{array}$ & $\begin{array}{c}-0.2073 \\
(-14.104)^{* *}\end{array}$ & $\begin{array}{c}-0.1974 \\
(-13.191)^{* * * *}\end{array}$ & $\begin{array}{c}-0.1326 \\
(-2.574) * * *\end{array}$ & $\begin{array}{c}-0.1907 \\
(-13.664) * * *\end{array}$ & $\begin{array}{c}-0.1809 \\
(- \\
12.708)^{* * *}\end{array}$ & $\begin{array}{c}-0.1983 \\
(- \\
13.165)^{* * *}\end{array}$ & $\begin{array}{c}-0.1833 \\
(-11.978)^{* * *}\end{array}$ & $\begin{array}{c}-0.1267 \\
(-2.605)^{* * *}\end{array}$ \\
\hline $\begin{array}{l}\text { Years of } \\
\text { education }\end{array}$ & $\begin{array}{c}0.0513 \\
(16.188)^{*} \\
* *\end{array}$ & $\begin{array}{c}0.0490 \\
(15.101)^{* * *}\end{array}$ & $\begin{array}{c}0.0515 \\
(15.113)^{* *} \\
*\end{array}$ & $\begin{array}{c}0.0503 \\
(14.522)^{* * *}\end{array}$ & $\begin{array}{c}0.0245 \\
(1.995)^{* *}\end{array}$ & $\begin{array}{c}0.0478 \\
(15.050)^{* * *}\end{array}$ & $\begin{array}{c}0.0455 \\
(14.039)^{* *} \\
*\end{array}$ & $\begin{array}{c}0.0463 \\
(13.556)^{* *} \\
*\end{array}$ & $\begin{array}{c}0.0467 \\
(13.475)^{* * *}\end{array}$ & $\begin{array}{l}0.0231 \\
(2.008)^{* *}\end{array}$ \\
\hline $\begin{array}{c}\text { Years of } \\
\text { employment }\end{array}$ & $\begin{array}{c}0.0379 \\
(10.645)^{*} \\
* *\end{array}$ & $\begin{array}{c}0.0345 \\
(9.469) * * *\end{array}$ & $\begin{array}{c}0.0361 \\
(9.516) * * \\
*\end{array}$ & $\begin{array}{c}0.0332 \\
(8.584)^{* * *}\end{array}$ & $\begin{array}{c}0.0262 \\
(2.342)^{* *}\end{array}$ & $\begin{array}{c}0.0363 \\
(10.230) * * *\end{array}$ & $\begin{array}{c}0.0330 \\
(9.047)^{* *} \\
*\end{array}$ & $\begin{array}{c}0.0321 \\
(8.537)^{* * *}\end{array}$ & $\begin{array}{c}0.0317 \\
*(8.191)^{* * *}\end{array}$ & $\begin{array}{c}0.0265 \\
(2.414)^{* *}\end{array}$ \\
\hline $\begin{array}{l}\text { Employment } \\
\text { years squared }\end{array}$ & $\begin{array}{c}-0.0006 \\
(- \\
6.929)^{* * *}\end{array}$ & $\begin{array}{c}-0.0005 \\
(-5.769)^{* * *}\end{array}$ & $\begin{array}{c}-0.0005 \\
(- \\
5.711)^{* * *}\end{array}$ & $\begin{array}{c}-0.0005 \\
(-5.266)^{* * *}\end{array}$ & $\begin{array}{l}-0.0004 \\
(-1.463)\end{array}$ & $\begin{array}{c}-0.0006 \\
(-6.428)^{* * *}\end{array}$ & $\begin{array}{c}-0.0005 \\
(- \\
5.816)^{* * *}\end{array}$ & $\begin{array}{c}-0.0005 \\
(- \\
5.349)^{* * *}\end{array}$ & $\begin{array}{c}-0.0005 \\
(-5.339)^{* * *}\end{array}$ & $\begin{array}{l}-0.0004 \\
(-1.607)\end{array}$ \\
\hline \multicolumn{11}{|l|}{ Occupation } \\
\hline $\begin{array}{l}\text { Nonmanual } \\
\text { worker }\end{array}$ & $\begin{array}{c}0.3067 \\
(12.084)^{*} \\
* *\end{array}$ & $\begin{array}{c}0.2885 \\
(11.147)^{* * *}\end{array}$ & $\begin{array}{c}0.2926 \\
(10.771)^{* *} \\
*\end{array}$ & $\begin{array}{c}0.2745 \\
(9.956)^{* * *}\end{array}$ & $\begin{array}{c}0.2799 \\
(3.213)^{* * *}\end{array}$ & $\begin{array}{c}0.2778 \\
(10.882)^{* * *}\end{array}$ & $\begin{array}{c}0.2608 \\
(10.018)^{* *}( \\
*\end{array}$ & $\begin{array}{c}0.2745 \\
(10.075)^{* * *}\end{array}$ & $\begin{array}{c}0.2473 \\
(8.921)^{* * *}\end{array}$ & $\begin{array}{c}0.2610 \\
(3.227)^{* *} \\
*\end{array}$ \\
\hline $\begin{array}{l}\text { Production } \\
\text { worker }\end{array}$ & $\begin{array}{c}0.0918 \\
(3.392)^{* *} \\
*\end{array}$ & $\begin{array}{c}0.0797 \\
(2.886) * * *\end{array}$ & $\begin{array}{c}0.0868 \\
(2.987)^{* *} \\
*\end{array}$ & $\begin{array}{l}0.0758 \\
(2.571)^{* *}\end{array}$ & $\begin{array}{c}0.1279 \\
(1.815)^{*}\end{array}$ & $\begin{array}{c}0.0911 \\
(3.381)^{* * *}\end{array}$ & $\begin{array}{c}0.0792 \\
(2.882)^{* *} \\
*\end{array}$ & $\begin{array}{c}0.0857 \\
(2.957) * * \\
*\end{array}$ & $\begin{array}{c}0.0758 \\
(2.579)^{* *}\end{array}$ & $\begin{array}{c}0.1260 \\
(1.836)^{*}\end{array}$ \\
\hline Self-employed & $\begin{array}{c}0.3938 \\
(4.038)^{* *} \\
*\end{array}$ & $\begin{array}{c}0.3658 \\
(3.717)^{* * *}\end{array}$ & $\begin{array}{c}0.3779 \\
(3.603)^{* *} \\
*\end{array}$ & $\begin{array}{c}0.3558 \\
(3.363)^{* * *}\end{array}$ & $\begin{array}{c}0.5338 \\
(3.802)^{* *} \\
*\end{array}$ & $\begin{array}{c}0.3820 \\
(3.905)^{* * *}\end{array}$ & $\begin{array}{c}0.3548 \\
(3.593)^{* *} \\
*\end{array}$ & $\begin{array}{c}0.5188 \\
(4.768)^{* * *}\end{array}$ & $\begin{array}{c}0.3451 \\
(3.248)^{* * *}\end{array}$ & $\begin{array}{c}0.5315 \\
(3.851)^{* *} \\
*\end{array}$ \\
\hline $\begin{array}{c}\text { Other } \\
\text { occupation }\end{array}$ & $\begin{array}{c}0.1123 \\
(3.154)^{* *} \\
*\end{array}$ & $\begin{array}{c}0.1085 \\
(2.957) * * *\end{array}$ & $\begin{array}{c}0.0983 \\
(2.519)^{* *} \\
*\end{array}$ & $\begin{array}{c}0.1023 \\
(2.553)^{* * *}\end{array}$ & $\begin{array}{c}0.1664 \\
(1.952)^{*}\end{array}$ & $\begin{array}{c}0.1037 \\
(2.916)^{* * *}\end{array}$ & $\begin{array}{c}0.1000 \\
(2.729)^{* *} \\
*\end{array}$ & $\begin{array}{c}0.1182 \\
(3.034)^{* * *}\end{array}$ & $\begin{array}{c}0.0946 \\
(2.362)^{* *}\end{array}$ & $\begin{array}{c}0.1628 \\
(1.945)^{*}\end{array}$ \\
\hline \multicolumn{11}{|l|}{$\frac{\text { Sector of }}{\text { Employer }}$} \\
\hline State sector & $\begin{array}{c}0.2867 \\
(12.778)^{* * *}\end{array}$ & $\begin{array}{c}0.2492 \\
(10.699)^{* * *}\end{array}$ & $\begin{array}{c}0.3073 \\
(12.818)^{* *} \\
*\end{array}$ & $\begin{array}{c}0.2728 \\
(11.057)^{* * *}\end{array}$ & $\begin{array}{c}0.2819 \\
(4.382)^{* * *}\end{array}$ & $\begin{array}{c}0.2787 \\
(12.462)^{* * *}\end{array}$ & $\begin{array}{c}0.2416 \\
(10.403)^{* *} \\
*\end{array}$ & $\begin{array}{c}0.2625 \\
(11.539)^{* *} \\
*\end{array}$ & $\begin{array}{c}0.2638 \\
(10.740)^{* * *}\end{array}$ & $\begin{array}{c}0.2740 \\
(4.446)^{* * *}\end{array}$ \\
\hline Private sector & $\begin{array}{c}0.3121 \\
(9.432)^{* *} \\
*\end{array}$ & $\begin{array}{c}0.2751 \\
(8.050)^{* * *}\end{array}$ & $\begin{array}{c}0.3255 \\
(8.988)^{* *} \\
*\end{array}$ & $\begin{array}{c}0.2934 \\
(7.876)^{* * *}\end{array}$ & $\begin{array}{c}0.3465 \\
(4.570)^{* *} \\
*\end{array}$ & $\begin{array}{c}0.3157 \\
(9.567)^{* * *}\end{array}$ & $\begin{array}{c}0.2788 \\
(8.170)^{* *} \\
*\end{array}$ & $\begin{array}{c}0.3108 \\
(7.317)^{* * *}\end{array}$ & $\begin{array}{c}0.2952 \\
(7.948)^{* * *}\end{array}$ & $\begin{array}{c}0.3426 \\
(4.648)^{* *} \\
*\end{array}$ \\
\hline$\frac{\text { Cities }}{\text { Beijing }}$ & $\begin{array}{c}0.6626 \\
(17.598) * * *\end{array}$ & $\begin{array}{c}0.6521 \\
(16.859)^{* * *}\end{array}$ & $\begin{array}{c}0.6856 \\
(16.621)^{* *}\end{array}$ & $\begin{array}{c}0.6770 \\
(16.014)^{* * *}\end{array}$ & $\begin{array}{c}0.7484 \\
(8.450)^{* * *}\end{array}$ & $\begin{array}{c}0.6743 \\
(17.916)^{* * *}\end{array}$ & $\begin{array}{c}0.6624 \\
(17.103)^{* *}\end{array}$ & $\begin{array}{c}0.6907 \\
(16.473)^{* *}\end{array}$ & $\begin{array}{c}0.6910 \\
(16.212)^{* * *}\end{array}$ & $\begin{array}{c}0.7553 \\
(8.828)^{* * *}\end{array}$ \\
\hline
\end{tabular}




\begin{tabular}{|c|c|c|c|c|c|c|c|c|c|c|}
\hline Shenyang & $\begin{array}{c}0.1887 \\
(4.720)^{* *} \\
*\end{array}$ & $\begin{array}{c}0.1724 \\
(4.192)^{* * *}\end{array}$ & $\begin{array}{c}0.1861 \\
(4.329)^{* *} \\
*\end{array}$ & $\begin{array}{c}0.1675 \\
(3.802)^{* * *}\end{array}$ & $\begin{array}{c}0.2856 \\
(3.100) * * \\
*\end{array}$ & $\begin{array}{c}0.1939 \\
(4.859) * * *\end{array}$ & $\begin{array}{c}0.1763 \\
(4.291)^{* *} \\
*\end{array}$ & $\begin{array}{c}0.1847 \\
(4.256) * * *\end{array}$ & $\begin{array}{c}0.1730 \\
(3.920)^{* * *}\end{array}$ & $\begin{array}{c}0.2875 \\
(3.212)^{* *} \\
*\end{array}$ \\
\hline Jinzhou & $\begin{array}{c}0.1381 \\
(2.942)^{* *} \\
*\end{array}$ & $\begin{array}{c}0.1204 \\
(2.485)^{* * *}\end{array}$ & $\begin{array}{c}0.1558 \\
(3.120)^{* *} \\
*\end{array}$ & $\begin{array}{c}0.1363 \\
(2.636) * * *\end{array}$ & $\begin{array}{l}0.1525 \\
(1.411)\end{array}$ & $\begin{array}{c}0.1414 \\
(3.009)^{* * *}\end{array}$ & $\begin{array}{c}0.1226 \\
(2.527)^{* *} \\
*\end{array}$ & $\begin{array}{c}0.1544 \\
(3.047)^{* * *}\end{array}$ & $\begin{array}{c}0.1399 \\
(2.701)^{* * *}\end{array}$ & $\begin{array}{l}0.1526 \\
(1.444)\end{array}$ \\
\hline Nanjing & $\begin{array}{c}0.5375 \\
(14.182)^{* * *}\end{array}$ & $\begin{array}{c}0.5140 \\
(13.219)^{* * *}\end{array}$ & $\begin{array}{c}0.5598 \\
(13.484)^{* *} \\
*\end{array}$ & $\begin{array}{c}0.5381 \\
(12.631)^{* * *}\end{array}$ & $\begin{array}{c}0.8715 \\
(4.282) * * *\end{array}$ & $\begin{array}{c}0.5562 \\
(14.647)^{* * * *}\end{array}$ & $\begin{array}{c}0.5309 \\
(13.606)^{* *} \\
*\end{array}$ & $\begin{array}{c}0.5711 \\
(13.560)^{* *} \\
*\end{array}$ & $\begin{array}{c}0.5565 \\
(12.992)^{* * *}\end{array}$ & $\begin{array}{c}0.8717 \\
(4.441)^{* * *}\end{array}$ \\
\hline Xuzhou & $\begin{array}{c}0.3489 \\
(7.607)^{* *} \\
*\end{array}$ & $\begin{array}{c}0.3225 \\
(6.902)^{* * *}\end{array}$ & $\begin{array}{c}0.3647 \\
(7.612)^{* *} \\
*\end{array}$ & $\begin{array}{c}0.3354 \\
(6.861)^{* * *}\end{array}$ & $\begin{array}{l}0.1580 \\
(1.224)\end{array}$ & $\begin{array}{c}0.3560 \\
(7.768) * * *\end{array}$ & $\begin{array}{c}0.3284 \\
(7.023)^{* *} \\
*\end{array}$ & $\begin{array}{c}0.3655 \\
(7.560)^{* * *}\end{array}$ & $\begin{array}{c}0.3430 \\
* \quad(6.997)^{* * *}\end{array}$ & $\begin{array}{l}0.1706 \\
(1.331)\end{array}$ \\
\hline Zhengzhou & $\begin{array}{c}0.1969 \\
(4.410)^{* *} \\
*\end{array}$ & $\begin{array}{c}0.2068 \\
(4.526)^{* * *}\end{array}$ & $\begin{array}{c}0.2097 \\
(4.377)^{* *} \\
*\end{array}$ & $\begin{array}{c}0.2218 \\
(4.508)^{* * *}\end{array}$ & $\begin{array}{c}0.4370 \\
(3.713)^{* *} \\
*\end{array}$ & $\begin{array}{c}0.1947 \\
(4.370)^{* * *}\end{array}$ & $\begin{array}{c}0.2032 \\
(4.454)^{* *} \\
*\end{array}$ & $\begin{array}{c}0.1981 \\
(4.099) * * *\end{array}$ & $\begin{array}{c}0.2204 \\
(4.481)^{* *} \\
*\end{array}$ & $\begin{array}{c}0.4294 \\
(3.722)^{* *} \\
*\end{array}$ \\
\hline Kaifeng & $\begin{array}{c}-0.2341 \\
(- \\
4.310) * * *\end{array}$ & $\begin{array}{c}-0.2289 \\
(-4.104)^{* * *}\end{array}$ & $\begin{array}{c}-0.2301 \\
(- \\
3.932)^{* * *}\end{array}$ & $\begin{array}{c}-0.2237 \\
(-3.732)^{* * *}\end{array}$ & $\begin{array}{l}0.0665 \\
(0.395)\end{array}$ & $\begin{array}{c}-0.2137 \\
(-3.941)^{* * *}\end{array}$ & $\begin{array}{c}-0.2099 \\
(- \\
3.770) * * *\end{array}$ & $\begin{array}{c}-0.2157 \\
(- \\
3.645) * * *\end{array}$ & $\begin{array}{l}-0.2037 \\
(-3.397)^{* * *}\end{array}$ & $\begin{array}{l}0.0746 \\
(0.461)\end{array}$ \\
\hline Pingdingshan & $\begin{array}{c}0.2559 \\
(5.138)^{* *} \\
*\end{array}$ & $\begin{array}{c}0.2532 \\
(4.984)^{* * *}\end{array}$ & $\begin{array}{c}0.2411 \\
(4.608) * * \\
*\end{array}$ & $\begin{array}{c}0.2340 \\
(4.383)^{* * *}\end{array}$ & $\begin{array}{l}0.0474 \\
(0.301)\end{array}$ & $\begin{array}{c}0.2533 \\
(5.121) * * *\end{array}$ & $\begin{array}{c}0.2498 \\
(4.947) * * \\
*\end{array}$ & $\begin{array}{c}0.2372 \\
(4.518) * * *\end{array}$ & $\begin{array}{c}0.2329 \\
(4.382) * * *\end{array}$ & $\begin{array}{l}0.0583 \\
(0.378)\end{array}$ \\
\hline Chengdu & $\begin{array}{c}0.2677 \\
(6.640)^{* *} \\
*\end{array}$ & $\begin{array}{c}0.2503 \\
(6.084)^{* * *}\end{array}$ & $\begin{array}{c}0.2900 \\
(6.653)^{* *} \\
*\end{array}$ & $\begin{array}{c}0.2733 \\
(6.140)^{* * *}\end{array}$ & $\begin{array}{l}0.1586 \\
(1.330)\end{array}$ & $\begin{array}{c}0.2779 \\
(6.899) * * *\end{array}$ & $\begin{array}{c}0.2590 \\
(6.294) * * \\
*\end{array}$ & $\begin{array}{c}0.2947 \\
(6.676) * * \\
*\end{array}$ & $\begin{array}{c}0.2839 \\
(6.357) * * *\end{array}$ & $\begin{array}{l}0.1704 \\
(1.470)\end{array}$ \\
\hline Zigong & $\begin{array}{l}-0.0155 \\
(-0.323)\end{array}$ & $\begin{array}{l}-0.0498 \\
(-1.030)\end{array}$ & $\begin{array}{l}0.0282 \\
(0.538)\end{array}$ & $\begin{array}{l}-0.0099 \\
(-0.187)\end{array}$ & $\begin{array}{l}0.0431 \\
(0.448)\end{array}$ & $\begin{array}{l}-0.0184 \\
(-0.385)\end{array}$ & $\begin{array}{l}-0.0537 \\
(-1.111)\end{array}$ & $\begin{array}{l}0.0157 \\
(0.296)\end{array}$ & $\begin{array}{l}-0.0113 \\
(-0.215)\end{array}$ & $\begin{array}{l}0.0384 \\
(0.408)\end{array}$ \\
\hline Nanchong & $\begin{array}{c}0.1084 \\
(2.310)^{* *} \\
*\end{array}$ & $\begin{array}{c}0.0949 \\
(1.962)^{* *}\end{array}$ & $\begin{array}{c}0.1337 \\
(2.665)^{* *} \\
*\end{array}$ & $\begin{array}{c}0.1159 \\
(2.266) * *\end{array}$ & $\begin{array}{c}0.2264 \\
(2.082)^{* *}\end{array}$ & $\begin{array}{c}0.1143 \\
(2.446) * *\end{array}$ & $\begin{array}{c}0.0992 \\
(2.058)^{*} \\
*\end{array}$ & $\begin{array}{c}0.1451 \\
(2.882)^{* *} \\
*\end{array}$ & $\begin{array}{c}0.1196 \\
(2.343) * *\end{array}$ & $\begin{array}{c}0.2278 \\
(2.154) * *\end{array}$ \\
\hline Lanzhou & $\begin{array}{c}0.1475 \\
(3.499)^{* *} \\
*\end{array}$ & $\begin{array}{c}0.1337 \\
(3.088)^{* * *}\end{array}$ & $\begin{array}{c}0.1367 \\
(2.873)^{* *} \\
*\end{array}$ & $\begin{array}{c}0.1275 \\
(2.609)^{* * *}\end{array}$ & $\begin{array}{l}-0.0263 \\
(-0.203)\end{array}$ & $\begin{array}{c}0.1568 \\
(3.724)^{* * *}\end{array}$ & $\begin{array}{c}0.1416 \\
(3.269)^{* *} \\
*\end{array}$ & $\begin{array}{c}0.1414 \\
(2.944)^{* *} \\
*\end{array}$ & $\begin{array}{c}0.1383 \\
(2.826) * * *\end{array}$ & $\begin{array}{l}-0.0073 \\
(-0.056)\end{array}$ \\
\hline $\begin{array}{c}\text { Inverse Mills } \\
\text { Ratio }\end{array}$ & --- & $\begin{array}{c}-0.5024 \\
(- \\
18.792)^{* * *}\end{array}$ & --- & $\begin{array}{c}-0.4862 \\
(-13.963)^{* * *}\end{array}$ & --- & --- & $\begin{array}{c}-0.5002 \\
(- \\
17.442)^{* * *}\end{array}$ & --- & $\begin{array}{c}-0.4843 \\
(-13.443) * * *\end{array}$ & --- \\
\hline $\mathrm{R}^{2}$ & 0.3057 & --- & 0.3110 & --- & --- & 0.3110 & --- & 0.1647 & --- & --- \\
\hline $\mathrm{F}(22,3909)$ & & --- & --- & --- & --- & --- & --- & --- & --- & --- \\
\hline $\mathrm{F}(23,3504)$ & $131.38 * * *$ & --- & $109.56 * *$ & --- & --- & --- & --- & --- & --- & --- \\
\hline $\mathrm{F}(23,2972)$ & --- & --- & $*$ & --- & $29.17 * * *$ & --- & --- & --- & --- & --- \\
\hline $\mathrm{F}(23,3907)$ & --- & --- & --- & --- & --- & $129.95 * * *$ & --- & --- & --- & --- \\
\hline $\mathrm{F}(24,3503)$ & --- & --- & --- & --- & --- & --- & --- & $108.21 * *$ & --- & --- \\
\hline $\mathrm{F}(24,2971)$ & --- & --- & --- & --- & --- & --- & --- & $\begin{array}{c}* \\
---\end{array}$ & --- & $28.89 * *$ \\
\hline $\begin{array}{l}\text { Wald } X^{2}(22) \\
\text { Wald } X^{2}(23)\end{array}$ & --- & $\begin{array}{c}2482.73 * * * \\
---\end{array}$ & --- & $2214.81^{---} * *$ & --- & --- & $2575.40 * *$ & --- & --- & $*$ \\
\hline Wald $X^{2}(24)$ & --- & --- & --- & --- & --- & --- & $\begin{array}{c}* \\
---\end{array}$ & --- & $2293.88 * * *$ & $\begin{array}{l}--- \\
---\end{array}$ \\
\hline $\begin{array}{l}\text { Number of } \\
\text { observations }\end{array}$ & 7546 & 7546 & 6572 & 6572 & 2973 & 7540 & 7540 & 6568 & 6568 & --- \\
\hline
\end{tabular}

Source: Urban Household Survey, 1999.

Notes: (1) Omitted dummy variables are: non-Communist Party members, urban collective sector, unskilled workers, and Pingliang.

(2) $* * *$ denotes statistical significance at the $1 \%$ level, $* *$ at $5 \%$ level, and $*$ at $10 \%$ level.

(3) Heteroskedasticity-consistent robust adjusted for clustering at the household level are computed.

(4) The exclusion restriction for equations (2), (4), (7), and (9) is whether childcare is available in the home. It is a dummy variable that equals one if there are grandparents who are living in the household and a child under the age of 17 . The variable is equal to zero if there is a child in the household and not grandparents or if there are not children in the household. 
(5) The instrument for social networks in equations (5) and (10) is an attitudinal question that asked: "Has the

importance of political status, which influence household income, changed compared with before?" Answers were (1) decreased; (2) unchanged; (3) increased. The instrument for Communist Party membership in equations (8) and (10) is a dummy variable that equals zero if an individual's father is/was an unskilled worker and equals one otherwise. Social networks are endogenous while Communist Party membership is not endogenous in these estimations. 
Table 4

The Determinants of Income for Employed Individuals Partitioned into those in Reformed and Less Reformed Provinces

\begin{tabular}{|c|c|c|c|c|c|c|c|c|c|c|}
\hline \multirow{4}{*}{$\begin{array}{l}\frac{\text { Dependent }}{\text { Variable: }} \\
\text { Log of annual } \\
\text { income }\end{array}$} & \multicolumn{10}{|c|}{$\begin{array}{l}\text { Coefficient } \\
\text { (t-statistic) }\end{array}$} \\
\hline & \multicolumn{6}{|c|}{ Beijing and Jiangsu } & \multicolumn{4}{|c|}{ Gansu and Sichuan } \\
\hline & (1) & (2) & (3) & (4) & (5) & (6) & (7) & (8) & (9) & (10) \\
\hline & MLE & $\begin{array}{c}2 \text { SLS } \\
\text { with SN }\end{array}$ & $\begin{array}{c}\text { MLE } \\
\text { with CP }\end{array}$ & $\begin{array}{c}\text { MLE } \\
\text { with SN } \\
\text { and CP }\end{array}$ & $\begin{array}{c}2 \mathrm{SLS} \\
\text { with SN } \\
\text { and CP }\end{array}$ & MLE & $\begin{array}{c}2 \text { SLS } \\
\text { with SN }\end{array}$ & $\begin{array}{c}\text { MLE } \\
\text { with CP }\end{array}$ & $\begin{array}{c}\text { MLE } \\
\text { with SN } \\
\text { and CP }\end{array}$ & $\begin{array}{c}2 \mathrm{SLS} \\
\text { with SN } \\
\text { and } \mathrm{CP}\end{array}$ \\
\hline Intercept & 7.8965 & 7.9550 & $\begin{array}{c}7.9127 \\
(49.076)^{* *}\end{array}$ & $\begin{array}{c}7.9643 \\
(44.972)^{* * *}\end{array}$ & $\begin{array}{c}7.9702 \\
(16.400) * * *\end{array}$ & 7.4118 & $\begin{array}{c}7.1314 \\
(21.666)^{* *}\end{array}$ & $\begin{array}{c}7.4531 \\
(118.294)^{* *}\end{array}$ & $\begin{array}{c}7.4832 \\
(111.368)^{* *}\end{array}$ & $\begin{array}{c}7.1657 \\
(22.155)^{* *}\end{array}$ \\
\hline & $(48.894) * * *$ & $\begin{array}{c}(16.541)^{* *} \\
*\end{array}$ & $*$ & & & $(117.289)^{* * *}$ & $*$ & $*$ & $*$ & $*$ \\
\hline \multicolumn{11}{|l|}{ Guanxi } \\
\hline $\begin{array}{c}\text { Social } \\
\text { network }\end{array}$ & --- & $\begin{array}{l}0.0770 \\
(0.991)\end{array}$ & --- & $\begin{array}{l}0.0003 \\
(0.251)\end{array}$ & $\begin{array}{l}0.0771 \\
(0.992)\end{array}$ & --- & $\begin{array}{c}0.1024 \\
(1.736)^{*}\end{array}$ & -- & $\begin{array}{l}\mathbf{0 . 0 0 4 4} \\
(3.080)^{* * * *}\end{array}$ & $\begin{array}{c}0.0977 \\
(1.700) *\end{array}$ \\
\hline $\begin{array}{c}\text { Communist } \\
\text { Party } \\
\text { member } \\
\text { Personal }\end{array}$ & --- & --- & $\begin{array}{l}0.0996 \\
(1.453)\end{array}$ & $\begin{array}{l}0.1398 \\
(1.859)^{*}\end{array}$ & $\begin{array}{l}0.0850 \\
(0.626)\end{array}$ & --- & --- & $\begin{array}{c}0.1134 \\
(6.908)^{* * *}\end{array}$ & $\begin{array}{l}0.1083 \\
(6.244)^{* * *}\end{array}$ & $\begin{array}{c}0.0752 \\
(1.776)^{*}\end{array}$ \\
\hline \multicolumn{11}{|l|}{ Characteristics } \\
\hline Gender & $\begin{array}{c}-0.2828 \\
(- \\
6.581)^{* * *}\end{array}$ & $\begin{array}{c}-0.2199 \\
(- \\
2.302)^{* * *}\end{array}$ & $\begin{array}{c}-0.2752 \\
(-6.287)^{* * *}\end{array}$ & $\begin{array}{c}-0.2613 \\
(-5.506) * * *\end{array}$ & $\begin{array}{c}-0.2167 \\
(-2.277)^{* *}\end{array}$ & $\begin{array}{c}-0.1667 \\
(-13.111) * * *\end{array}$ & $\begin{array}{l}-0.0835 \\
(-1.512)\end{array}$ & $\begin{array}{c}-0.1541 \\
(- \\
11.799)^{* * *}\end{array}$ & $\begin{array}{c}-0.1530 \\
(- \\
11.021)^{* * *}\end{array}$ & $\begin{array}{l}-0.0796 \\
(-1.521)\end{array}$ \\
\hline $\begin{array}{l}\text { Years of } \\
\text { education }\end{array}$ & $\begin{array}{c}0.0260 \\
(2.781)^{* *} \\
*\end{array}$ & $\begin{array}{l}-0.0149 \\
(-0.571)\end{array}$ & $\begin{array}{c}0.0235 \\
(2.484)^{*} \\
*\end{array}$ & $\begin{array}{c}0.0188 \\
(1.868)^{*}\end{array}$ & $\begin{array}{l}-0.0179 \\
(-0.663)\end{array}$ & $\begin{array}{c}0.0434 \\
(13.835)^{* * *}\end{array}$ & $\begin{array}{c}0.0195 \\
(1.708)^{*}\end{array}$ & $\begin{array}{c}0.0405 \\
(12.885)^{*} \\
* *\end{array}$ & $\begin{array}{c}0.0409 \\
(12.143)^{*} \\
* *\end{array}$ & $\begin{array}{c}0.0189 \\
(1.748)^{*}\end{array}$ \\
\hline $\begin{array}{c}\text { Years of } \\
\text { employment }\end{array}$ & $\begin{array}{c}0.0284 \\
(2.555)^{* *}\end{array}$ & $\begin{array}{l}0.0035 \\
(0.128)\end{array}$ & $\begin{array}{c}0.0284 \\
(2.265)^{* *} \\
*\end{array}$ & $\begin{array}{c}0.0272 \\
(1.990) * *\end{array}$ & $\begin{array}{l}0.0034 \\
(0.126)\end{array}$ & $\begin{array}{c}0.0426 \\
(11.598)^{* * *}\end{array}$ & $\begin{array}{c}0.0272 \\
(2.135)^{*} \\
*\end{array}$ & $\begin{array}{c}0.0410 \\
(11.167)^{*} \\
* *\end{array}$ & $\begin{array}{c}0.0357 \\
(9.254)^{* *} \\
*\end{array}$ & $\begin{array}{c}0.0274 \\
(2.214)^{*} \\
*\end{array}$ \\
\hline $\begin{array}{l}\text { Employment } \\
\text { years squared }\end{array}$ & $\begin{array}{l}-0.0005 \\
(-1.293)\end{array}$ & $\begin{array}{l}0.0001 \\
(0.126)\end{array}$ & $\begin{array}{l}-0.0005 \\
(-1.373)\end{array}$ & $\begin{array}{l}-0.0004 \\
(-1.169)\end{array}$ & $\begin{array}{l}0.0001 \\
(0.100)\end{array}$ & $\begin{array}{c}-0.0008 \\
(-8.321)^{* * *}\end{array}$ & $\begin{array}{c}-0.0005 \\
(- \\
1.703)^{*}\end{array}$ & $\begin{array}{c}-0.0007 \\
(- \\
8.309)^{* * *}\end{array}$ & $\begin{array}{c}-0.0006 \\
(- \\
6.785)^{* * *}\end{array}$ & $\begin{array}{c}-0.0005 \\
(- \\
1.823)^{*}\end{array}$ \\
\hline$\frac{\text { Sector of }}{\text { Employer }}$ & Yes & Yes & Yes & Yes & Yes & Yes & Yes & Yes & Yes & Yes \\
\hline$\overline{\text { Occupation }}$ & Yes & Yes & Yes & Yes & Yes & Yes & Yes & Yes & Yes & Yes \\
\hline$\frac{\frac{\text { Number of }}{\text { days not }}}{\text { worked }}$ & $\begin{array}{c}-0.0021 \\
(-13.194) * * *\end{array}$ & $\begin{array}{c}-0.0020 \\
(- \\
6.833)^{* * *}\end{array}$ & $\begin{array}{c}-0.0021 \\
(- \\
13.148)^{* * *}\end{array}$ & $\begin{array}{c}-0.0022 \\
(-12.781)^{* * *}\end{array}$ & $\begin{array}{c}-0.0020 \\
(-6.722) * * *\end{array}$ & --- & --- & --- & --- & --- \\
\hline$\overline{\underline{\text { Cities }}}$ & Yes & Yes & Yes & Yes & Yes & Yes & Yes & Yes & Yes & Yes \\
\hline $\begin{array}{l}\text { Inverse Mills } \\
\text { Ratio }\end{array}$ & $\begin{array}{l}0.0617 \\
(1.110)\end{array}$ & --- & $\begin{array}{l}0.0538 \\
(0.949)\end{array}$ & $\begin{array}{l}0.0647 \\
(0.973)\end{array}$ & --- & $\begin{array}{c}-0.2206 \\
(-1.791)^{*}\end{array}$ & --- & $\begin{array}{l}-0.2275 \\
(-2.060)^{* *}\end{array}$ & $\begin{array}{l}-0.0823 \\
(-0.719)\end{array}$ & --- \\
\hline $\mathrm{R}^{2}$ & --- & --- & --- & --- & --- & --- & --- & --- & --- & --- \\
\hline $\mathrm{F}(24,512)$ & --- & $7.71 * * *$ & --- & --- & --- & --- & --- & --- & --- & --- \\
\hline $\mathrm{F}(25,512)$ & --- & --- & --- & --- & $7.29 * * *$ & --- & --- & --- & --- & --- \\
\hline $\mathrm{F}(23,2319)$ & --- & --- & --- & --- & --- & --- & & --- & --- & --- \\
\hline $\mathrm{F}(24,2318)$ & --- & --- & --- & --- & --- & --- & $16.83 * * *$ & --- & --- & \\
\hline Wald $X^{2}(22)$ & --- & --- & --- & --- & --- & $2095.85 * * *$ & --- & --- & --- & $16.92 * *$ \\
\hline Wald $X^{2}(23)$ & $453.75 * * *$ & --- & --- & --- & --- & -- & --- & $2152.42 * *$ & --- & $*$ \\
\hline Wald $X^{2}(24)$ & --- & --- & $453.71 * * *$ & --- & --- & --- & --- & $*$ & $1914.44 * * *$ & --- \\
\hline Wald $X^{2}(25)$ & --- & --- & --- & $421.04 * * *$ & --- & --- & --- & --- & --- & --- \\
\hline $\begin{array}{l}\text { Number of } \\
\text { observations }\end{array}$ & 1114 & 513 & 1113 & 962 & 653 & 6110 & --- & --- & 5344 & $\begin{array}{l}--- \\
---\end{array}$ \\
\hline & & & & & & & 2320 & 6105 & & 2319 \\
\hline
\end{tabular}

Source: Urban Household Survey, 1999.

Notes: (1) Omitted dummy variables are: non-Communist Party members, urban collectives, unskilled workers, and Pingliang.

(2) $* * *$ denotes statistical significance at the $1 \%$ level, $* *$ at $5 \%$ level, and $*$ at $10 \%$ level.

(3) Heteroskedasticity-consistent robust adjusted for clustering at the household level are computed. 
(4) The exclusion restriction for equations (1) and (4) is whether the individual owns his home. The variable is equal to one and zero if otherwise. It is thought to capture individual economic motivation or drive are able to negotiate the purchase of their homes after housing allocation ceased to be part of the in-kind benefits of state sector employment. For equations (6) and (9), it is having childcare in the home.

(5) The instrument for social networks is an attitudinal question that asked: "Has the importance of political status, which influence household income, changed compared with before?" Answers were (1) decreased; (2) unchanged; (3) increased. The instrument for Communist Party membership is based on the following question: "Do you hope your children will join the Communist Party?" Answers were (1) no; (2) little; (3) some; (4) very much. A dummy variable equals zero if the answer was either (1) or (2) and equals one otherwise. Social networks are endogenous while Communist Party membership is not endogenous. 
Table 5

The Determinants of Income for Employed Individuals by Age Cohorts

\begin{tabular}{|c|c|c|c|c|c|c|c|c|c|c|}
\hline \multirow{4}{*}{$\begin{array}{l}\frac{\text { Dependent }}{\text { Variable: }} \\
\text { Log of annual } \\
\text { income }\end{array}$} & \multicolumn{10}{|c|}{$\begin{array}{l}\text { Coefficient } \\
(\mathrm{t}-\text { statistic })\end{array}$} \\
\hline & \multicolumn{3}{|c|}{ Ages 19-30 } & \multicolumn{3}{|c|}{ Ages $31-41$} & \multicolumn{4}{|c|}{ Ages 42-55 } \\
\hline & (1) & (2) & (3) & (4) & (5) & (6) & (7) & (8) & (9) & (10) \\
\hline & MLE & $\begin{array}{c}\text { MLE } \\
\text { with SN }\end{array}$ & $\begin{array}{c}\text { MLE } \\
\text { with CP }\end{array}$ & MLE & $\begin{array}{c}\text { MLE } \\
\text { with SN }\end{array}$ & $\begin{array}{c}\text { MLE } \\
\text { with CP }\end{array}$ & MLE & $\begin{array}{c}\text { 2SLS } \\
\text { with SN }\end{array}$ & $\begin{array}{c}\text { MLE } \\
\text { with CP }\end{array}$ & $\begin{array}{c}\text { 2SLS } \\
\text { with SN } \\
\text { CP, } \\
\text { PCP }\end{array}$ \\
\hline Intercept & $\begin{array}{c}7.6034 \\
(48.638)^{* * *}\end{array}$ & $\begin{array}{c}7.5465 \\
(42.479) * * *\end{array}$ & 7.6157 & 7.6083 & $\begin{array}{c}7.3360 \\
(50.127) * *\end{array}$ & $\begin{array}{c}7.6389 \\
(53.555)^{* * *}\end{array}$ & $\begin{array}{c}7.4601 \\
(52.770)^{* * *}\end{array}$ & 7.1544 & $\begin{array}{c}7.5043 \\
(53.254) * *\end{array}$ & $\begin{array}{c}7.1844 \\
(32.385)^{* * *}\end{array}$ \\
\hline Guanxi & & & $(48.020) * * *$ & $(53.072)^{* * *}$ & $*$ & & & $(32.185)^{* * *}$ & $*$ & \\
\hline $\begin{array}{c}\text { Social } \\
\text { network }\end{array}$ & --- & $\begin{array}{c}0.0037 \\
(\mathbf{1 . 8 5 6})^{*}\end{array}$ & --- & --- & $\begin{array}{c}0.0099 \\
(4.463)^{* * *}\end{array}$ & --- & --- & $\begin{array}{l}0.0266 \\
(0.983)\end{array}$ & --- & $\begin{array}{l}\mathbf{0 . 0 2 5 9} \\
(\mathbf{0 . 9 7 7 )}\end{array}$ \\
\hline $\begin{array}{c}\text { Communist } \\
\text { Party } \\
\text { member } \\
\text { Personal } \\
\text { Characteristics }\end{array}$ & --- & --- & $\begin{array}{c}\mathbf{0 . 1 6 1 7} \\
(2.701)^{* *} \\
*\end{array}$ & --- & --- & $\begin{array}{c}0.1344 \\
(4.558)^{* * *}\end{array}$ & --- & --- & $\begin{array}{c}0.1299 \\
(5.542)^{* *} \\
*\end{array}$ & $\begin{array}{c}0.1229 \\
(3.140)^{* * *}\end{array}$ \\
\hline Gender & $\begin{array}{c}-0.1886 \\
(- \\
4.584)^{* * *}\end{array}$ & $\begin{array}{c}-0.2178 \\
(-5.022) * * *\end{array}$ & $\begin{array}{c}-0.1789 \\
(- \\
4.495)^{* * *}\end{array}$ & $\begin{array}{c}-0.1962 \\
(-8.451)^{* * *}\end{array}$ & $\begin{array}{c}-0.2193 \\
(- \\
9.098)^{* * *}\end{array}$ & $\begin{array}{c}-0.1811 \\
(- \\
7.672)^{* * *}\end{array}$ & $\begin{array}{c}-0.1970 \\
(- \\
10.180)^{* * *}\end{array}$ & $\begin{array}{c}-0.1373 \\
(- \\
3.775)^{* * *}\end{array}$ & $\begin{array}{c}-0.1828 \\
(- \\
9.223)^{* * *}\end{array}$ & $\begin{array}{c}-0.1296 \\
(- \\
3.570)^{* * *}\end{array}$ \\
\hline $\begin{array}{l}\text { Years of } \\
\text { education }\end{array}$ & $\begin{array}{c}0.0307 \\
(3.441)^{* *} \\
*\end{array}$ & $\begin{array}{c}0.0391 \\
(3.916)^{* * *}\end{array}$ & $\begin{array}{c}0.0298 \\
(3.319)^{* *} \\
*\end{array}$ & $\begin{array}{c}0.0583 \\
(9.952)^{* * *}\end{array}$ & $\begin{array}{c}0.0559 \\
(9.127)^{* *} \\
*\end{array}$ & $\begin{array}{c}0.0541 \\
(9.245)^{* *} \\
*\end{array}$ & $\begin{array}{c}0.0459 \\
(10.386)^{* *} \\
*\end{array}$ & $\begin{array}{c}0.0334 \\
(4.663)^{* *} \\
*\end{array}$ & $\begin{array}{c}0.0420 \\
(9.485)^{* *} \\
*\end{array}$ & $\begin{array}{c}0.0289 \\
(4.197)^{*} \\
* *\end{array}$ \\
\hline $\begin{array}{c}\text { Years of } \\
\text { employment }\end{array}$ & $\begin{array}{c}0.0689 \\
(3.233)^{* *} \\
*\end{array}$ & $\begin{array}{c}0.0607 \\
(2.446)^{* *}\end{array}$ & $\begin{array}{c}0.0682 \\
(3.171)^{* *} \\
*\end{array}$ & $\begin{array}{l}-0.0006 \\
(-0.044)\end{array}$ & $\begin{array}{l}0.0150 \\
(1.016)\end{array}$ & $\begin{array}{l}-0.0010 \\
(-0.072)\end{array}$ & $\begin{array}{c}0.0204 \\
(2.012)^{* *}\end{array}$ & $\begin{array}{c}0.0379 \\
(2.332)^{*} \\
*\end{array}$ & $\begin{array}{c}0.0197 \\
(1.941)^{*}\end{array}$ & $\begin{array}{c}0.0373 \\
(2.316)^{*} \\
*\end{array}$ \\
\hline $\begin{array}{l}\text { Employment } \\
\text { years squared }\end{array}$ & $\begin{array}{c}-0.0025 \\
(-1.691)^{*}\end{array}$ & $\begin{array}{l}-0.0025 \\
(-1.456)\end{array}$ & $\begin{array}{c}-0.0026 \\
(-1.714)^{*}\end{array}$ & $\begin{array}{l}0.0004 \\
(1.015)\end{array}$ & $\begin{array}{c}0.00001 \\
(0.032)\end{array}$ & $\begin{array}{l}0.0004 \\
(0.949)\end{array}$ & $\begin{array}{l}-0.0002 \\
(-0.985)\end{array}$ & $\begin{array}{l}-0.0005 \\
(-1.570)\end{array}$ & $\begin{array}{l}-0.0002 \\
(-1.028)\end{array}$ & $\begin{array}{l}-0.0005 \\
(-1.591)\end{array}$ \\
\hline$\frac{\text { Sector of }}{\underline{\text { Employer }}}$ & Yes & Yes & Yes & Yes & Yes & Yes & Yes & Yes & Yes & Yes \\
\hline Occupation & Yes & Yes & Yes & Yes & Yes & Yes & Yes & Yes & Yes & Yes \\
\hline Cities & Yes & Yes & Yes & Yes & Yes & Yes & Yes & Yes & Yes & Yes \\
\hline $\begin{array}{l}\text { Inverse Mills } \\
\text { Ratio }\end{array}$ & $\begin{array}{c}-0.5679 \\
(- \\
11.257)^{* * *}\end{array}$ & $\begin{array}{c}-0.5894 \\
(-10.507)^{* * *}\end{array}$ & $\begin{array}{c}-0.5705 \\
(- \\
11.719)^{* * *}\end{array}$ & $\begin{array}{c}-0.5634 \\
(-12.264)^{* * * *}\end{array}$ & $\begin{array}{l}-0.0022 \\
(-0.040)\end{array}$ & $\begin{array}{c}-0.5607 \\
(- \\
13.779)^{* * *}\end{array}$ & $\begin{array}{c}-0.4684 \\
(-9.839)^{* * * *}\end{array}$ & --- & $\begin{array}{c}-0.4804 \\
(- \\
110.07)^{* *} \\
*\end{array}$ & --- \\
\hline $\mathrm{R}^{2}$ & --- & --- & --- & --- & --- & --- & --- & 0.2204 & --- & 0.2329 \\
\hline $\mathrm{F}(23,1548)$ & --- & --- & --- & --- & --- & --- & --- & & --- & --- \\
\hline $\mathrm{F}(26,1548)$ & --- & --- & --- & --- & --- & --- & --- & $26.81 * * *$ & --- & \\
\hline Wald $X^{2}(22)$ & & --- & --- & & --- & --- & & --- & --- & $24.27 * *$ \\
\hline Wald $X^{2}(23)$ & $416.62 * * *$ & $345.75 * * *$ & $448.20 * *$ & $902.68 * *$ & $949.98 * *$ & $943.03 * * *$ & $1283.82 * *$ & --- & $1306.52 * *$ & $*$ \\
\hline $\begin{array}{l}\text { Number of } \\
\text { observations }\end{array}$ & --- & 1074 & * & $\begin{array}{c}* \\
---\end{array}$ & & 2677 & $\begin{array}{c}* \\
---\end{array}$ & --- & $*$ & $\begin{array}{l}--- \\
---\end{array}$ \\
\hline & 1320 & & 1315 & 2678 & 2392 & & 3548 & 1549 & 3548 & 1549 \\
\hline
\end{tabular}

Source: Urban Household Survey, 1999.

Notes: (1) Omitted dummy variables are: non-Communist Party members, urban collective sector, unskilled workers, parents who are not Communist Party members, and Pingliang.

(2) $* * *$ denotes statistical significance at the $1 \%$ level, $* *$ at $5 \%$ level, and $*$ at $10 \%$ level.

(3) Heteroskedasticity-consistent robust adjusted for clustering at the household level are computed.

(4) The exclusion restriction is a dummy variable that equals 1 if the individual is in poor health.

(5) The instrument for social networks is an attitudinal question that asked: "Has the importance of political status, which influence household income, changed compared with before?" Answers were (1) decreased; (2) unchanged; (3) increased. For the second age cohort, the instrument for social networks was the question: "Have the importance of social connections, which is thought to influence household income, changed as compared with before?" Answers were (1) decreased; (2) unchanged; (3) increased. 
The instrument for Communist Party membership is a dummy variable that equals zero if an individual's father is/was an unskilled worker and equals one otherwise. For the first age cohort, the instrument for Communist Party membership is the question: "Do you hope your children will join the Communist Party?" Answers were (1) no; (2) little; (3) some; (4) very much. Social networks are endogenous, while Communist Party membership is not endogenous in the third age cohort and was not endogenous at the $5 \%$ level for the other age cohorts. 
Table 6

The Determinants of Income for Employed Individuals by Ownership Sector of Employer

\begin{tabular}{|c|c|c|c|c|c|c|c|c|c|c|}
\hline \multirow{6}{*}{$\begin{array}{c}\text { Dependent } \\
\frac{\text { Variable: }}{\text { Log of }} \\
\text { annual } \\
\text { income }\end{array}$} & & & & & & & & & & \\
\hline & \multirow{2}{*}{\multicolumn{10}{|c|}{$\begin{array}{l}\text { Coefficient } \\
\text { (t-statistic) }\end{array}$}} \\
\hline & & & & & & & & & & \\
\hline & \multicolumn{4}{|c|}{ SOE } & \multicolumn{2}{|c|}{ Urban Collectives } & \multicolumn{2}{|c|}{ Self-Employed } & \multicolumn{2}{|c|}{ Private Firms } \\
\hline & (1) & (2) & (3) & (4) & (5) & (6) & (7) & (8) & (9) & (10) \\
\hline & MLE & $\begin{array}{c}\text { MLE } \\
\text { with SN }\end{array}$ & $\begin{array}{c}\text { MLE } \\
\text { with CP }\end{array}$ & $\begin{array}{c}\text { MLE } \\
\text { with SN } \\
\text { and CP }\end{array}$ & MLE & $\begin{array}{c}\text { MLE } \\
\text { with SN } \\
\text { and CP }\end{array}$ & MLE & $\begin{array}{c}\text { MLE } \\
\text { with SN } \\
\text { and CP }\end{array}$ & MLE & $\begin{array}{c}\text { MLE } \\
\text { with SN } \\
\text { and CP }\end{array}$ \\
\hline Intercept & $\begin{array}{c}8.0445 \\
(103.186)^{* *} \\
*\end{array}$ & $\begin{array}{c}8.0365 \\
(96.145)^{* * *}\end{array}$ & $\begin{array}{c}8.0538 \\
(103.961)^{*} \\
* *\end{array}$ & $\begin{array}{c}8.0459 \\
(96.621)^{* * *}\end{array}$ & $\begin{array}{c}7.9159 \\
(29.321)^{* *} \\
*\end{array}$ & $\begin{array}{c}7.9755 \\
(26.756) * * *\end{array}$ & $\begin{array}{c}8.4406 \\
(25.177)^{* *} \\
*\end{array}$ & $\begin{array}{c}8.3633 \\
(21.955)^{* *} \\
*\end{array}$ & $\begin{array}{c}7.7155 \\
(16.250)^{* *} \\
*\end{array}$ & $\begin{array}{c}8.0948 \\
(9.628)^{* * *}\end{array}$ \\
\hline $\begin{array}{c}\text { Guanxi } \\
\text { Social } \\
\text { network }\end{array}$ & --- & $\begin{array}{c}\mathbf{0 . 0 0 7 1} \\
(3.165)^{* * *}\end{array}$ & --- & $\begin{array}{c}\mathbf{0 . 0 0 6 6} \\
(3.041)^{* * *}\end{array}$ & --- & $\begin{array}{c}0.0110 \\
(2.570)^{* * *}\end{array}$ & --- & $\begin{array}{l}-0.0004 \\
(-0.678)\end{array}$ & --- & $\begin{array}{c}\text { 0.0140 } \\
(\mathbf{3 . 0 3 0})^{* *} \\
*\end{array}$ \\
\hline $\begin{array}{c}\begin{array}{c}\text { Communist } \\
\text { Party } \\
\text { member }\end{array} \\
\text { Personal } \\
\text { Characteristics } \\
\end{array}$ & --- & --- & $\begin{array}{c}\mathbf{0 . 1 4 6 1} \\
(7.787)^{* *} \\
*\end{array}$ & $\begin{array}{c}0.1362 \\
(6.743)^{* * * *}\end{array}$ & --- & $\begin{array}{l}\mathbf{0 . 1 2 3 2} \\
(1.765) *\end{array}$ & --- & $\begin{array}{l}-0.2162 \\
(-1.012)\end{array}$ & --- & $\begin{array}{c}0.1823 \\
(2.481)^{* *}\end{array}$ \\
\hline Gender & $\begin{array}{c}-0.1540 \\
(- \\
10.084)^{* * *}\end{array}$ & $\begin{array}{c}-0.1522 \\
(-9.369)^{* * *}\end{array}$ & $\begin{array}{c}-0.1379 \\
(- \\
8.801)^{* * *}\end{array}$ & $\begin{array}{c}-0.1370 \\
(-8.211)^{* * *}\end{array}$ & $\begin{array}{c}-0.2532 \\
(- \\
5.606)^{* * *}\end{array}$ & $\begin{array}{c}-0.2624 \\
(-5.409)^{* * *}\end{array}$ & $\begin{array}{c}-0.2123 \\
(- \\
2.642)^{* * *}\end{array}$ & $\begin{array}{c}-0.2857 \\
(- \\
3.222)^{* * *}\end{array}$ & $\begin{array}{c}-0.2601 \\
(- \\
4.665)^{* * *}\end{array}$ & $\begin{array}{c}-0.2146 \\
(- \\
3.442)^{* *} \\
*\end{array}$ \\
\hline $\begin{array}{l}\text { Years of } \\
\text { education }\end{array}$ & $\begin{array}{c}0.0500 \\
(14.433)^{*} \\
* *\end{array}$ & $\begin{array}{c}0.0492 \\
(13.453)^{* * *}\end{array}$ & $\begin{array}{c}0.0453 \\
(13.058)^{* *} \\
*\end{array}$ & $\begin{array}{c}0.0448 \\
(12.247) * * *\end{array}$ & $\begin{array}{c}0.0474 \\
(4.492) * * \\
*\end{array}$ & $\begin{array}{c}0.0396 \\
(3.562)^{* * *}\end{array}$ & $\begin{array}{l}0.0158 \\
(0.859)\end{array}$ & $\begin{array}{l}0.0291 \\
(1.412)\end{array}$ & $\begin{array}{l}0.0227 \\
(1.474)\end{array}$ & $\begin{array}{l}0.0025 \\
(0.142)\end{array}$ \\
\hline $\begin{array}{c}\text { Years of } \\
\text { employment }\end{array}$ & $\begin{array}{c}0.0314 \\
(7.200)^{* *} \\
*\end{array}$ & $\begin{array}{c}0.0295 \\
(6.496)^{* * *}\end{array}$ & $\begin{array}{c}0.0293 \\
(6.730)^{* *} \\
*\end{array}$ & $\begin{array}{c}0.0276 \\
(6.077)^{* * *}\end{array}$ & $\begin{array}{c}0.0323 \\
(2.938)^{* *} \\
*\end{array}$ & $\begin{array}{c}0.0315 \\
(2.660) * * *\end{array}$ & $\begin{array}{c}0.0695 \\
(3.465)^{* *} \\
*\end{array}$ & $\begin{array}{c}0.0574 \\
(2.678) * * *\end{array}$ & $\begin{array}{c}0.0558 \\
(4.218)^{* *} \\
*\end{array}$ & $\begin{array}{c}0.0638 \\
(4.349)^{* *} \\
*\end{array}$ \\
\hline $\begin{array}{l}\text { Employment } \\
\text { years squared }\end{array}$ & $\begin{array}{c}-0.0004 \\
(- \\
4.035)^{* * *}\end{array}$ & $\begin{array}{c}-0.0004 \\
(-3.703) * * *\end{array}$ & $\begin{array}{c}-0.0004 \\
(- \\
4.051)^{* * *}\end{array}$ & $\begin{array}{c}-0.0004 \\
(-3.726)^{* * *}\end{array}$ & $\begin{array}{c}-0.0006 \\
(- \\
2.313)^{* *}\end{array}$ & $\begin{array}{c}-0.0006 \\
(-2.172)^{* *}\end{array}$ & $\begin{array}{c}-0.0015 \\
(- \\
2.311)^{* *}\end{array}$ & $\begin{array}{c}-0.0012 \\
(-1.682)^{*}\end{array}$ & $\begin{array}{c}-0.0012 \\
(- \\
3.247)^{* *} \\
*\end{array}$ & $\begin{array}{c}-0.0015 \\
(- \\
3.616)^{* *} \\
*\end{array}$ \\
\hline Occupation & Yes & Yes & Yes & Yes & Yes & Yes & Yes & Yes & Yes & Yes \\
\hline$\underline{\text { Cities }}$ & Yes & Yes & Yes & Yes & Yes & Yes & Yes & Yes & Yes & Yes \\
\hline $\begin{array}{c}\text { Inverse Mills } \\
\text { Ratio }\end{array}$ & $\begin{array}{c}-0.5155 \\
(- \\
18.435)^{* * *}\end{array}$ & $\begin{array}{c}-0.5057 \\
(- \\
16.355)^{* * *}\end{array}$ & $\begin{array}{c}-0.5197 \\
(-19.116)^{* * *}\end{array}$ & $\begin{array}{c}-0.5102 \\
(-17.053) * * *\end{array}$ & $\begin{array}{c}-0.5821 \\
(- \\
10.054) * * *\end{array}$ & $\begin{array}{c}-0.5325 \\
(-6.161)^{* * *}\end{array}$ & $\begin{array}{c}0.6575 \\
(12.170)^{* * *}\end{array}$ & $\begin{array}{c}0.6472 \\
(10.846)^{* *} \\
*\end{array}$ & $\begin{array}{c}-0.6842 \\
(- \\
18.009)^{* * *}\end{array}$ & $\begin{array}{c}-0.6742 \\
(- \\
15.438)^{* * *}\end{array}$ \\
\hline Wald $X^{2}(7)$ & --- & --- & --- & --- & --- & --- & & --- & --- & --- \\
\hline Wald $X^{2}(9)$ & --- & --- & --- & --- & --- & --- & $33.50 * * *$ & & --- & --- \\
\hline Wald $X^{2}(11)$ & --- & --- & --- & --- & -- & --- & --- & $31.49 * * *$ & & --- \\
\hline Wald $X^{2}(15)$ & --- & --- & --- & --- & --- & --- & --- & --- & $97.50 * * *$ & \\
\hline Wald $X^{2}(17)$ & $1644.13 * *$ & --- & --- & --- & & --- & --- & --- & --- & $127.82 * * *$ \\
\hline Wald $X^{2}(18)$ & $*$ & & & --- & $250.30^{* *}$ & --- & --- & --- & --- & --- \\
\hline Wald $X^{2}(19)$ & --- & $1434.96 * * *$ & $1716.11 * *$ & $1491.71 * * *$ & $*$ & $274.14 * * *$ & --- & --- & --- & --- \\
\hline $\begin{array}{l}\text { Number of } \\
\text { observations }\end{array}$ & --- & --- & $\begin{array}{l}* \\
---\end{array}$ & 4883 & $\begin{array}{l}--- \\
---\end{array}$ & 916 & --- & --- & --- & --- \\
\hline & 5585 & 4887 & 5580 & & 1039 & & 238 & 199 & 523 & 437 \\
\hline
\end{tabular}

Source: Urban Household Survey, 1999.

Notes: (1) Omitted dummy variables are: non-Communist Party members, unskilled workers, and Pingliang.

(2) $* * *$ denotes statistical significance at the $1 \%$ level, $* *$ at $5 \%$ level, and $*$ at $10 \%$ level.

(3) Heteroskedasticity-consistent robust adjusted for clustering at the household level are computed. 
(4) The exclusion restriction is a dummy variable that is equal to 1 if the individual is in poor health and zero otherwise for the state sector. For urban collectives and private firms, the exclusion restriction is a dummy variable that is equal to 1 if the individual has no drive and zero otherwise, based on the question: "Do you agree or disagree with the following statement in order to secure a stable household standard of living in the long run? Don't want to do much apart from following the crowd." Answers: (1) agree; (2) disagree. For selfemployed individuals, the exclusion restriction is a dummy variable that is equal to 1 if the individual had been laid-off in the five years between the end of 1994 to the end of 1999 and zero otherwise.

(5) The instrument for social networks is an attitudinal question that asked: "Has the importance of political status, which influence household income, changed compared with before?" Answers were (1) decreased; (2) unchanged; (3) increased. The instrument for Communist Party membership is a dummy variable that equals zero if an individual's father is/was an unskilled worker and equals one otherwise. Social networks and Communist Party membership are endogenous for the state sector at the $10 \%$ level and not any of the other sectors. Thus, we report maximum likelihood estimates for all estimations. 